\title{
The Economics of Uniform Laws and Uniform Law Making
}

John Linarelli

Touro Law Center, jlinarelli@tourolaw.edu

Follow this and additional works at: https://digitalcommons.tourolaw.edu/scholarlyworks

Part of the Commercial Law Commons, Comparative and Foreign Law Commons, and the International Law Commons

\section{Recommended Citation}

48 Wayne L. Rev. 1387

This Article is brought to you for free and open access by the Faculty Scholarship at Digital Commons @ Touro Law Center. It has been accepted for inclusion in Scholarly Works by an authorized administrator of Digital Commons @ Touro Law Center. For more information, please contact Iross@tourolaw.edu. 


\title{
THE ECONOMICS OF UNIFORM LAWS AND UNIFORM LAWMAKING
}

\author{
JOHN LINARELLI ${ }^{\dagger}$
}

A foolish consistency is the hobgoblin of little minds, adored by little statesmen and philosophers and divines. ${ }^{\prime}$

\section{Table of Contents}

I. INTRODUCTION .......................... 1389

II. THE NORMATIVE ECONOMICS OF UNIFICATION . . . . . . . . . 1395

A. General Considerations ..................... 1395

B. Efficiency Arguments Supporting Unification ........ 1397

1. The Strategic Characteristics of International

Commercial Transactions ................. 1397

a. Default Rules Analysis . . . . . . . . . . . . . . 1398

b. Contractual Choice of Law .............. 1404

i. Questioning the Question ............. 1405

ii. Efficiency Concerns About Contractual Choice of Law ..................... 1406

iii. Distributional Concerns About Contractual

Choice of Law ................... 1409

2. Unification and Path Dependence ............ 1410

†Associate Professor of Law, University of LaVeme College of Law. B.A., 1981, Duquesne University; J.D., 1985, The American University Washington College of Law; L.L.M. 1995, Georgetown University Law Center. Parts of this article were written when I was Senior Lecturer in Law at the Norwich Law School of the University of East Anglia, in England. I wish to offer my thanks to members of the Norwich Law School faculty who kindly provided comments on a draft of this article in a research seminar, including Caroline Ball, Claudina Richards, David Mead, Andrew Scott, Keith Syrett, Christiane Trüe, and Glynis Truter. I would also like to offer my thanks for comments provided by Kenneth Westphal, Chair in Philosophy at East Anglia, both in and beyond the seminar. Ken is always there with inspiration and ideas. A major inspiration for this article was the opportunity to present an abbreviated version of it at the American Society of International Law Annual Meeting in Washington D.C., on March 15, 2002. I wish to thank the British Society of Legal Scholars for funding to attend the meeting, and participants in the panel at which the paper was presented, including Helen Hartnell, who served as panel chair, Ralf Michaels, Paul Stephan and Janet Walker, as well as those who attended the panel presentation. My sincerest gratitude to Albert Kritzer and Peter Winship for their encouragement. Finally, a special thanks to Alastair Mullis, my Dean at UEA, who I cannot thank enough for his support throughout the years. The usual disclaimers apply.

1. Ralph Waldo Emerson, Self Reliance, in SELF RELIANCE AND OTHER ESSAYS (1841). 
III. The Positive EConomics of the Unification Process $\ldots .1415$

A. General Considerations .................... 1415

B. Domestic Interest Groups Thwarting International

Improvements: The Capture of the Domestic Lawmaking

Process

1. The WIPO Copyright Treaty and the US Digital

Millennium Copyright Act ................ 1419

2. The British Refusal to Ratify the CISG ......... 1426

a. The Conventional Reasons .............. 1427

b. The Reasons Through the Lens of Public Choice .. 1429

i. Legal London Has Benefited from Legal

Diversity .................... 1430

ii. Lawyers Outside of the International Commercial

Legal Establishment Either Are Rationally

Ignorant of Unification Efforts or Prefer

Unification ..................... 1435

iii. The British Legal Establishment Prefers

International Cooperation in Areas Outside of

Commercial Law .................... 1436

iv. The Proposition that English Law Is "Superior"

to International Conventions and the Domestic

Laws of Other Countries Has Significant

Cultural Meaning but Is Largely Myth

v. The Established Commodity Associations Exclude

Uniform Sales Laws from Application ..... 1439

C. States Unify Around Institutional Blockage: The Harmonizing

Tendencies of the EU Constitutional Order .......... 1442

IV. CONCLUSIONS: SOME MODEST RECOMMENDATIONS ........ 1445

A. Commentaries Addressing Efficiency . . . . . . . . . 1445

B. Random Reviews ......................... 1446

C. Improving International Institutions $\ldots \ldots \ldots \ldots \ldots 1446$ 


\section{INTRODUCTION}

Uniform lawmaking has a substantial history in the twentieth century. ${ }^{2}$ It seems to be continuing with some force into the twenty-first century. ${ }^{3} \mathrm{~A}$ significant American law and economics literature, however, questions its merit. ${ }^{4}$ A European literature has emerged as well. ${ }^{5}$ Critics of the uniform

2. To avoid confusion, I use the term "unification" to mean the process by which governments minimize the differences among legal systems in particular areas of the law by adopting common principles of law. I do not distinguish between "unification" and "harmonization." In a prior work, I used the term "harmonization" to mean the same thing. John Linarelli, The Economics of Private Law Harmonization, 96 AM. SOC'Y OF INT'L L. PROCEEDINGS 339 (2002). I expend precious little effort in this article exploring the conceptual differences between codification and other less direct forms of unification. Holding true to economically oriented inquiry, an analysis of terminological differences is beyond the scope of this article, and not very useful in furthering an understanding of the important questions in any event.

3. It is beyond the scope of this article to catalogue the unification efforts ongoing worldwide. The efforts of the American Law Institute (ALI) and the National Conference of Uniform Law Commissions (NCUCL) enjoy a global reputation. The ALI restatements have influenced European lawyers to engage in significant academic discussion of the unification of private law in the European Union. See, e.g., Jürgen Basedow, The Renascence of Uniform Law: European Contract Law and Its Components, 18 LEGAL STUD. 121 (1998); Hugh Beale, The Europeanization of Contract Law, in EXPLORING THE BOUNDARIES OF CONTRACT 23 (R. Halson ed., 1996); Roy Goode, International Restatements and National Law, in The SEARCh fOR PRINCIPLE: EsSays IN HONOUR OF LORD GOFF OF ChIEVELEY 45 (Gareth Jones \& William Swadling eds., 1999); Roy Goode, International Restatements of Contract and English Contract Law, 2 UNIFORM L. REV. 231 (1997); Ole Lando, Centennial World Congress on Comparative Law: Comparative Law and Law Making, 75 TUL. L. REv. 1015 (2001); Ole Lando, The Common Core of European Private Law and the Principles of European Contract Law, 21 HASTINGS INT'L \& COMP. L. REV. 809 (1998); Ugo Mattei, $A$ Transactions Cost Approach to the European Code, 5 EUR. REV. PRIVATE L. 537 (1997). The European Commission has taken the debate beyond the academy and has sought input on what the European Union (EU) should do, if anything, to unify contract law in the EU. Communication from the European Commission to the Council and the European Parliament on European Contract Law, COM(2001) 398 final, July 11, 2001, available at http://europa.ev.int/comm/consumers/cons_int/safe_shop/ fair_bus_pract/cont_law/cont_law_02_en.pdg (last visited May 6, 2003).

4. See, e.g., Peter A. Alces \& David Frisch, On the UCC Revision Process: $A$ Reply to Dean Scott, 37 WM. \& MARY L. REV. 1217 (1996); Edward J. Kanger, 
Predicting When the Uniform Law Process Will Fail: Article 9, Capture, and the Race to the Bottom, 83 IOWA L. REV. 569 (1998); Kathleen Patchel, Interest Group Politics, Federalism, and the Uniform Laws Process: Some Lessons from the Uniform Commercial Code, 78 MiNN. L. REV. 83(1993); Larry E. Ribstein \& Bruce H. Kobayashi, An Economic Analysis of Uniform State Laws, 25 J. LEGAL STUD. 131 (1996); Alan Schwartz \& Robert E. Scott, The Political Economy of Private Legislatures, 143 U. PA. L. REV. 595 (1995); Robert E. Scott, Is Article 2 the Best We Can Do?, 52 Hastings L. J. 677 (2001); Robert E. Scott, The Politics of Article 9, 80 VA. L. REV. 1783 (1994); Steven L. Schwarcz, A Fundamental Inquiry into the Statutory Rulemaking Process of Private Legislatures, 29 GA. L. REV. 909 (1995); Paul B. Stephan, Accountability and International Lawmaking: Rules, Rents and Legitimacy, 17 Nw. J. INT'L L. \& BuS. 681 (1997); Paul B. Stephan, The Futility of Unification and Harmonization in International Commercial Law, 39 VA. J. INT'L L. 743 (1999) [hereinafter Stephan, Futility of Unification] Lisa Bernstein's seminal work on private legal systems challenges the underlying policy of the UCC drafters to emphasize course of dealing, course of performance, and trade usages. See Lisa Bemstein, Merchant Law in a Merchant Court; Rethinking the Code's Search for Immanent Business Norms, 144 U. PA. L. REV. 1765 (1996); Lisa Bernstein, Private Commercial Law in the Cotton Industry: Creating Cooperation Through Rules, Norms, and Institutions, 99 MiCH. L. REV. 1724 (2001); Lisa Bernstein, The Questionable Empirical Basis of Article 2's Incorporation Strategy: A Preliminary Study, 66 U. CHI. L. REV. 710 (1999). A substantial critical literature beyond and preceding law and economics critiques exists. See Arthur Rosett, Improving the Uniform Commercial Code, Lecture at CENTRO de StUdi E RICERCHE DI DIRITTO COMPaRato E STRANIERo, SAGGI, CONFERENZE ESEMINARE 29 (May 5, 1997), available at http://w3.uniromal.it/idc/ centro/publications/29rosett.pdf; Arthur Rosett, CISG Laid Bare: A Lucid Guide to a Muddy Code, 21 CoRnell INT'L L. J. 575 (1988); Arthur Rosett, Critical Reflections on the United Nations Convention on Contracts for the International Sale of Goods, 45 OHI STATE L. J. 265 (1984); Arthur Rosett, UNIDROIT Principles and Harmonization of International Commercial Law: Focus on Chapter Seven, 3 UNIFORM L. REV. 441 (1997). Criticisms go back to when the Uniform Commercial Code was being prepared and considered by states. See, e.g., Frederick K. Beutel, The Proposed Uniform Commercial Code as a Problem in Codification, 16 LAW \& CONTEMP. PROBS. 141 (1951); Frederick K. Beutel, The Proposed Uniform [?] Commercial Code Should Not be Adopted, 61 YALEL.J.334 (1952); Grant Gilmore, The Uniform Commercial Code: A Reply to Professor Beutel, 61 YALE L J. 364 (1952); Samuel Williston, The Law of Sales in the Proposed Uniform Commercial Code, 63 HARV. L. REV. 561 (1950). Not all of the scholarship identified here is critical. Supporters as well as detractors are identified.

5. See, e.g., Martjin W. Hesselink, The Politics of European Contract Law: Who has an Interest in What Kind of Contract Law for Europe?, 2 GLOBAL FRONTIERS, part 1, article 3 (2002), available at http://www.bepress.com/gj/ 
law movement in the United States use methods of analysis influenced by public choice theory, political economics, and positive political theory. This article does not call into question the methods and assumptions of these approaches, although economics seems to be so rich in theories that

frontiers/vol2/iss1/art3/current_ article.html (accessed by selecting "All Journals" the "Global Jurist" and selecting article under "frontiers") (last visited Mar. 20, 2003); Hein Kötz, Rechtsvereinheitlichung - Nutzen, Kosten, Methoden, Ziele, 50 RABEL ZEITSCHRIFT FÜR AUSLĀNDISCHES UND INTERNATIONALES PRIVATRECHT 483 (1986); Ugo Mattei, A Transaction Costs Approach to the European Code, 5 EUROPEAN REV. PRIVATE L. 537 (1997) (citing LUISA ANTONIOLlI DEFLORIAN, LA STRUTTURA INSTITUZIONALE DEL NUOVO DIRITTO COMUNE EUROPEO: COMPETIZIONE ECIRCOLAZIONE DEIMODELLIGUIRIDICI(1996); Rudolfo Sacco, The System of European Private Law: Premises for a European Code, in ITALIAN STUDIES IN LAW 71 (Allesandro Pizzorusso ed., Kluwer Academic Publishers 1992)); Norbert Reich, Competition Between Legal Orders: A New Paradigm of EC Law?, 29 COMMON MKT. L. REV. 861 (1992); Jan M. Smits, How to Predict the Differences in Uniformity between Different Areas of a Future European Private Law? An Evolutionary Approach, in THE ECONOMICS OF HARMONIZING EUROPEAN LAW 50 (Alain Marciano \& Jean-Michel Josselin, eds., 2002). Law and economics is less influential in Europe. A number of legal scholars who are not economically oriented inquire about unification. See, e.g., Pierre Legrand, Against a European Civil Code, 60 MOD. L. Rev. 44 (1997); Pierre Legrand, Are Civilians Educable?, 18 Legal STUd. 216(1998); Basil S. Markesinis, Why a Code is Not the Best Way to Advance the Cause of European Legal Unity, 5 EUR. REV. PRIVATE L. 519 (1997); Gunther Teubner, Legal Irritants: Good Faith in British Law or How Unifying Law Ends Up in New Divergences, 61 MOD. L. REV. 11 (1998). For discussions about the advantages and disadvantages of a European insurance code, see generally Jürgen Basedow, The Case for a European Insurance Contract Code, 2001 J. BuS. L. 569.(2001); Colin Croly \& Rob Merkin, Doubts About Insurance Codes, 2001 Journal OF BUSINESS LAW 587 (2001); Malcolm Clarke, Doubts from the Dark Side-The Case Against Codes, 2001 J. BuS. L. 605 (2001); Patrick Griggs, Insurance Codes-A Middle Way, 2001 J.Bus. L. 616 (2001); Anthony A. Tarr \& Julie-Anne Tar, Some Critical Legal Issues A fleeting Insurance Transactions Globally, 2001 J. BUS. L. 661 (2001). For research principally by political economists, see Smits, supra; BRUNO FREY \& REINER EICHENBERGER, THE NEW DEMOCRATIC FEDERALISM IN EUROPE: FunCTIONAL, OVERLAPPING AND COMPETING JURISDICTIONS (1999); Bruno Frey \& Reiner Eichenberger, FOCJ: Competitive Governments for Europe, 16 INT'L REV. L. ECON. 315 (1996); Bruno Frey \& Reiner Eichenberger, OFCJ: Creating a Single European Market for Governments, in CONSTrTUTIONAL LAW AND ECONOMICS IN THE EUROPEAN UNION 195 (Dieter Schmidtchen \& Robert Cooter eds., 1997). Many of the investigations by economists do not focus directly or principally on private or transactional law, but rather on public or regulatory law, often on EU law and EU legal institutions. 
it is difficult to produce predictions, at least at purely theoretical or conceptual levels, and because there are few ways to empirically test many of the propositions, we are left in many cases solely with argument. ${ }^{6}$

The strong thesis of this article is that economic analysis supports public policy in favor of unification of law if certain conditions, outlined in the article, are met. The weak thesis is that research to date on the question does not lead to the conclusion that governments should avoid unification as a general principle. A central pillar of these claims is that unification can lead to efficiency improvements in the law. These efficiency improvements can occur globally, such as between common markets and within common markets, such as within the United States or the European Union. Two questions must be explored to understand the effects of any law, one normative and the other positive. ${ }^{7}$ The normative question relevant to the focus of inquiry here is whether unified rules are more efficient than diverse rules. As explained in Part I below, the answer to this question is "they can be." Part I explains how economic analysis supports unification. The positive question is whether or not the rule making process leads to the production of efficient rules. In other words, in addition to looking at the end-result-the efficiency properties of the rules themselves-we have to look at how those rules are made in order to determine whether efficient rules will actually result from the uniform law

6. See Charles K. Rowley, Social Sciences and Law: The Relevance of Economic Theories, 1 OXFORD J. LEGAL STUD. 391 (1981).

7. The two main methods in the academic enterprise of law and economics are the analysis of the efficiency properties of legal rules and the analysis of the law making process to assess how it affects the contents of legal rules. The analysis of the efficiency properties of legal rules is normative because it supports the use of efficiency as a normative tool for determining the appropriate legal rule or public policy. The analysis of the law making process to assess how the law making process affects the contents of legal rules is positive because it explains or predicts the actual content of a legal rule by studying how it was made. The explanations of the positive-normative distinction are numerous and it is beyond the scope of this article to explore them here. See, e.g., Cass R. Sunstein, On Philosophy and Economics, 19 QUINNIPIAC L. REV. 333 (2000); Maxwell L. Stearns, Restoring Positive Law and Economics: Introduction to Public Choice Theme Issue, 6 GEO. MASON L. REV. 709 (1998); Avery Wiener Katz, Positivism and the Separation of Law and Economics, 94 MICH. L. REV. 2229 (1996); Herbert Hovenkamp, Positivism in Law and Economics, 78 CAL. L. REV. 815(1990). It is not the purpose of this article to examine these foundational issues in depth; they are mentioned here only because much of the scholarly examination of the economics of unification makes a muddle of the distinction. 
making process. As explained in Part II below, the answer to this second question is "it depends." Part II explains how political economics and public choice theory support arguments for the proper design of institutions to facilitate efficient unification. It is beyond challenge that the characteristics of the lawmaking process-institutions- affect the content of the substantive rules that are produced in any such process. ${ }^{8}$ This has been shown to be a predictive hypothesis in myriad institutional settings, but primarily in the analysis of the behavior of domestic legislatures. Part II throws into question the way questions are posed in the scholarly debate about unified versus diverse law. To make the analysis sufficiently general, we have to flip the question and ask about the effects of the process of making diverse or decentralized law on the content of the law. Decentralized institutions do not necessarily produce apolitical law because they can suffer from public choice problems too.

Before proceeding, more digression on what Part II seeks to explain. The question is not whether the institutions of unification are or are not subject to interest group capture, rent seeking or any of the other properties of a law making process that public choice theory predicts, but whether the workings of those institutions results in efficiency improvements over what actually exists in law making settings that do not involve unification, such as those which occur in domestic legislatures or domestic courts. It is unhelpful to benchmark institutions that unify law against some ideal set of incentives that nowhere exist. The comparison, in other words, should be between, as the context dictates, domestic legislatures and domestic courts (in common law countries) versus bodies that make or recommend unified rules. Any other comparison leads to needless question begging, a comparison with an idealized straw man that will never exist, resulting in the production of theory and evidence that is of marginal usefulness. We should be focusing our energies on design of institutions that minimize the production of inefficient law, not merely on blanket condemnations of all

8. The influential ideas on the effects of institutions on the substance of legal rules are found in public choice theory, positive political theory and new institutional economics. It would be impracticable to survey the substantial literature in these fields here. General references are: EMPIRICAL STUDIES IN INSTITUTIONAL CHANGE (Lee J. Alston et al. eds., 1996) (regarding new institutional economics, see in particular Douglass North's Nobel Prize Lecture in Economic Science); DenNis C. Mueller, PubliC ChOICE II (revised ed. 1989) (regarding public choice); KENNETH A. SHEPSLE \& MARK S. BONCHEK, ANALYZING POLITICS: RATIONALITY, BEHAVIOR, AND INSTITUTIONS (1997) (regarding positive political theory). 
unification. A corollary to this claim, and one that necessarily follows from rational choice methods, is that what is required is a close institutional analysis of each institutional process to determine what sorts of rules are produced. From these sorts of close analyses, no general conclusions, such as unification is "good" or "bad" can follow. All that we can determine is what, from a positive standpoint, are the effects of unification in particular settings, given the institutions particular to the unification efforts being examined.

Good economic theory is based on intuition about something observed in the world. It seems the intuition for the theory that gets built around rejection of unification is based on domestic experiences in the United States. The intuition in Europe leads to different theory. In Europe, where it is impossible to speak of a legal system based on a common epistemology, the cost-benefit calculus of the choices of either unifying some law or maintaining the current levels of substantial diversity are more likely to lead to the conclusion that unification can offer significant efficiency improvements. Contractual choice of law does not provide a practical solution. The diversity of transactional or private law in Europe makes contractual choice costly because current levels of diversity can impose substantial transaction costs at the point where contract parties have to make their choices. Moreover, from the standpoint of the positive economics of the law making process in the European countries, diversity sometimes continues because powerful interest groups have influenced the law making process away from unification in order to maintain competitive advantages in home markets. As explained in Part II below, states may seek diversity not because it is efficient, but because it maximizes the welfare of selected groups within their domestic constituencies. Legal diversity in this context may result in a net welfare loss, both within the borders of a country, or in a common market, or internationally.

Finally, as explained in Part I, the framing of the question as to whether law is unified or not may miss the essential elements of how law is produced and has evolved in Europe and elsewhere. Systems of law in all of the EU member states except England and Wales and Ireland are codified. A good argument can be made that even the common law is "codified" in the sense that is was rationalized by Blackstone, Coke and others. The question may not be whether unification produces better law than law that is diverse across jurisdictions. Rather, the question may be what kind of unification is preferred-at what level, domestic or international. Legal diversity is a continuum; it does not present itself in the law in action as an either-or proposition. 


\section{THE NORMATIVE ECONOMICS OF UNIFICATION}

\section{A. General Considerations}

One way of making the issues in this part of the article more concrete is to think of them in the context of the paradigmatic international documentary sale of goods transaction, as it is set forth in the standard texts on international commercial transactions in the United States and on international trade law in the United Kingdom. The documentary sale transaction is perhaps the easiest transaction to understand, given its firm grounding in contract and sales law and its strong intuitive appeal to lawyers generally. In the documentary sale transaction, $B$ contracts with $S$ for the purchase of a good. International sale of goods transactions pose the classic set of legal and business risks associated with non-simultaneous exchange at a distance, across borders and often in a setting where reputational and relational sanctions either do not exist or are inadequate to the task of protecting contracting parties. The parties face classic problems associated with asymmetric information and the inability to monitor each other's contractual obligations. One of the principal information impediments in these transactions is legal diversity across jurisdictions. Because more than one jurisdiction has an interest in the transaction ( $B$ and $S$ are in different countries and borders have to be crossed for the transaction to be accomplished), it may be uncertain which sets of legal rules apply to the transaction, and more than one set may apply, depending on the how the rules of private international law allocate jurisdiction. In addition to diversity of formal legal rules, there may be diversity of informal norms arguably applicable to the transaction. Different countries have different business customs. Finally, if a dispute arises in the transaction, dispute resolution may be more costly because courts foreign to one or more of the parties may hear the case, and because of the potential for forum shopping. This article deals principally with the first problem, which legal rules should apply to the transaction and whether the rules should be unified.'

9. For new scholarship on the economics of forum shopping, see Kimberly A. Moore \& Francesco Parisi, Rethinking Forum Shopping in Cyberspace, Geo. Mason L. \& Econ. Paper No. 02-01 available at http://papers.ssm.com (accessed from home page by entering title of article) (last visited Mar. 20, 2003). To mitigate information problems and strategic behavior associated with forum shopping, parties to international contracts often contractually select arbitration as a method of dispute resolution. 
To combat the familiar problems relating to lack of information and lack of assurances that contractual obligations will be met, including the above defects in the law, $B$ and $S$ use a number of costly intermediary institutions to accomplish exchange. These institutions have arisen largely as mercantile custom over the years. They provide $B$ and $S$ with means to unbundle and spread risk. In general, six such institutions are used: 1) the sales contract between $B$ and $S, 2$ ) the agreement between $B$ and its bank to issue a letter of credit on $S$ 's behalf, 3 ) the letter of credit itself, which is an agreement between $S$ and $B$ 's bank, 4) $S$ 's contract with a carrier to ship the goods to $B$, usually in the form of a bill of lading, 5) S's contract with an insurer to insure risk of loss of the goods during shipment, 6) a bill of exchange issued by $S$ in favor of $B$, which creates payment obligations and which is designed primarily as a tool to finance the transaction, because it can be negotiated. There may be other features of the transaction, such as loan agreements relating to financing of the purchase, or documents relating to compliance with governmental regulation of international trade, but for our purposes here, we are only concerned with those characteristics of the transaction designed to allocate risk associated with the international features of the transaction. ${ }^{10}$

The law associated with each of the above commercial institutions could be and indeed have been the subject of unification, in the forms of international conventions, model laws and standardization of custom and practice. A few examples are provided here. A number of countries have ratified the Vienna Convention on Contacts for the International Sale of Goods (the CISG), which applies to the sales contract." Some of the legal rules that unifying bodies seek to unify are in the areas where intermediaries operate. The International Chamber of Commerce (ICC) has attempted unification of banking practices associated with letters of credit, in its Uniform Customs and Practice for Documentary Credits (UCP). ${ }^{12}$ It

10. For standard treatments, see LEO D'ARCY, CAROL MURRAY \& BARBARA CLEAVE, SCHMITTHOFF'S EXPORT TRADE (10th ed. 2002); RALPH H. FOLSOM ET AL., INTERNATIONAL BUSINESS TRANSACTIONS: A PROBLEM-ORIENTEDCASEBOOK (4th ed. 2002).

11. For the text of the CISG and supporting materials, go to CISG On-Line, http://www.cisg-online.ch (accessed from homepage by entering "CISG" in search box) (last visited June 8, 2003). Also see Pace University's extensive website on the CISG, available at http://pace.edu (last visited May 6, 2003) (containing a Review and CISG database).

12. ICC No. 500, Uniform Customs AND PRACTICE FOR DOCUMENTARY CREDITS (1993). 
is standard practice to incorporate the UCP by reference into letters of credit. ${ }^{13}$ The sales contract between $B$ and $S$ may incorporate Incoterms, a set of standard contract terms, which the ICC has prepared, to define and allocate transportation risks between $B$ and $S .^{14}$ The maritime aspects of the international sales transaction are substantially regulated at the international level. The Hague Rules, Hague-Visby Rules and the Hamburg Rules govern the allocation of liability for loss at sea among carriers and shippers. ${ }^{15}$

\section{B. Efficiency Arguments Supporting Unification}

\section{The Strategic Characteristics of International Commercial Transactions}

Parties to contracts for the international sale of goods have a number of unilateral and bilateral strategic opportunities in the stages of contract formation, contract performance and ultimately, dispute resolution if one of the parties chooses to initiate litigation or some other form of contractually specified dispute resolution such as arbitration. ${ }^{16}$ As do transacting parties generally, parties to an international commercial transaction have incentives to engage in strategic behavior to manipulate costs and benefits in order to capture as much surplus as they can in a

13. The UCP favors the interests of banks over customers. See, e.g., Stephan, Futility of Unification, supra note 4, at 783. The UCP does not represent a classic set of norms to govern transactions of similarly situated traders, such as those that Lisa Bernstein has examined in her path breaking research. See discussion supra note 4. The UCP affects the rights of bank customers, who presumably have no input into their content, as well as banks, and thus has potentially serious implications for distribution and efficiency.

14. INTERNATIONAL CHAMBER OF COMMERCE, INCOTERMS 2000: ICCOFFICIAL RULES FOR THE INTERPRETATION OF TRADE TERMS (2000).

15. For the Hamburg Rules, go to http://www.uncitral.org (accessed by selecting "english" then selecting "search UNICATRAL" and entering "Hamburg Rules" in the search box) (last visited June 8, 2003). For the Hague Rules and Hague Visby Rules, go to http://www.jus.uio.no//m/sea.carriage.hague.visby.rules $.1968 / \mathrm{doc} . \mathrm{html}$. (The Hague Visby Rules are the Hague Rules as amended by the Brussels Protocol 1968.)

16. Arbitration is a standard method by which parties to international commercial transactions mitigate information problems associated with litigating in foreign courts. Courts are alternative dispute resolution institutions in such transactions. 
transaction. Strategic behavior imposes a cost on any transaction, domestic or international. Strategic behavior costs are:

[T]he losses suffered because bargainers have the incentive to maximize their individual gains rather than the total surplus from exchange. Since the potential surplus can be divided among the parties in various ways, the parties may invest real resources in hopes of altering the division. Or, they may act in ways that either destroys a portion of the surplus or that risk that the bargain will fall through. ${ }^{17}$

The strategic choices that rational (or boundedly rational) parties make are in part determined by the information that they have on the possible outcomes of any legal dispute arising from a failure to perform by the other party. The information available to a contract party depends on the relevant default and mandatory rules. What the relevant legal rules are is a much more important question when a transaction crosses a border. As explained below, legal diversity can create a host of information problems in an international transaction.

\section{a. Default Rules Analysis}

The information problems in international transactions are often substantial. ${ }^{18}$ In the absence of reputation or a relationship to provide information about contract parties to each other, contract parties face an

17. Avery W. Katz, The Strategic Structure of Offer and Acceptance, $89 \mathrm{MICH}$.

L. REV. 215, 226 (1990).

18. As Katz explains:

The problems of adverse selection and moral hazard are likely to be especially significant when parties contract at a distance. The difficulty of verifying information about a far-off and unfamiliar location, organized according to local conventions and possibly in a different language; the problems of collecting at a distance and navigating a foreign legal system; and the relative infrequency of such transactions, making it difficult to cover the overhead costs of investigation and enforcement or to establish a credible business reputation, all combine to make reliance on ex post legal enforcement an especially cumbersome tool to ensure compliance with contractual obligations.

Avery W. Katz, Informality as a Bilateral Assurance Mechanism: Comments on Ronald Mann's 'The Role of Letters of Credit in Payment Transactions', $98 \mathrm{MICH}$. L. REV. 2555, 2557 (2000). 
adverse selection problem. Contract parties cannot distinguish between high and low quality promises of contract performance. $B$ cannot determine whether $S$ 's promise that she will deliver the goods on time and in accordance with the quality standards of the contract is a high quality promise or a bad quality promise. $S$ cannot determine whether B's promise to pay for the goods is a good quality promise or a bad quality promise. ${ }^{19}$ By definition, both parties to the classic two-party international sales contract outlined above are dealing with opposing parties in foreign jurisdictions.

One set of informal norms that could take the place of formal law can be dismissed at the outset because they apply in a small number of cases. Reputational sanctions and relational contracting are weak substitutes for law in international commercial transactions. The strict conditions for reputational and relational norms are often not present in international contexts. In a typical international transaction for the sale of goods, parties are by definition from different legal jurisdictions. They may also have different cultures, and different business customs may prevail in the countries in which the traders base their activities. ${ }^{20}$ Formal legal rules,

19. The "lemons" literature does not furnish clear guidance on the application of its concepts. Some might argue that adverse selection is a problem only in a principal-agent setting, where the agent enjoys some informational advantage over the principal. In other words, adverse selection involves the situation where one party to the transaction knows more or has better information than the other party. See EIRIK G. FURUBOTN \& RUDOLF RICHTER, INSTITUTIONS AND ECONOMIC THEORY: THE CONTRIBUTION OF NEW INSTITUTIONAL ECONOMICS 179 (2000). Not all of the literature makes such a fine-grained distinction, and I use the adverse selection concept broadly here to cover any sort of informational disadvantage of either party to a transaction. Cf. Larry E. Ribstein \& Bruce H. Kobayashi, State Regulation of Electronic Commerce, GEO. MASON L. \& ECON., available at http://www.ssm.com (accessed from homepage by selecting Search \& Download Paper and entering keyword "State Regulation" and "Electronic Commerce") (last visited Jan. 28, 2003) (asserting that Internet transactions generally do not have adverse selection problems).

20. Scholars and lawyers are unable to agree on whether lex mercatoria exists in the present day, and if so what it is. Some would argue it includes custom. LEX MERCATORIA AND ARBITRATION: A Discussion OF THE NEW LAW MERCHANT (Thomas Carbonneau ed., 2000). Others question whether it exists. See, e.g., Francis Mann, Introduction, in LEX MERCATORIA AND ARBITRATION: ADISCUSSION OF THE NEW LAW MERCHANT xxiv (2000) ("No merchant of any experience would ever be prepared to submit to the unforeseeable consequences which arise from the application of undefined and undefinable standards described as rules of a lex of 
whether domestic or international in character, tend to be more important when informal norm structures are weak. In the context of contracting at a distance over borders, the costs of building reputation or relationships are substantial. Over-reliance on reputation and relationship would result in fewer international transactions and decrease international trade because they do not furnish adequate information on the quality of promises $B$ and $S$ make. Of course, this does not mean that relational contracting and reputational payoffs do not occur at the international level. Many firms do repeat business with one another transnationally, and many international commercial transactions are between affiliated firms. The point here is that if we had to rely on such extralegal norm structures to provide the essential basis for cooperation, then we would be precluding a significant number of exchange opportunities that do not fit this special case.

As explained above, costly protective measures such as letters of credit and bills of lading serve to unbundle risks and alleviate information problems to a certain extent. ${ }^{21}$ That such measures are used, however, does not detract from the basic proposition that improved legal certainty will also facilitate exchange and efficiency improvements. The measures themselves, moreover, rely on legal rules and merchant norms for their viability. Anything that reduces transaction costs should be welcomed. It could be that the protective measures may become less important as legal systems reach higher levels of convergence.

It is beyond dispute that law facilitates exchange. It has been recognized at least since the time of Hobbes and perhaps going back to Roman times that contract law is needed to deter people from acting opportunistically. ${ }^{22}$ Law is necessary to international transactions as it is to domestic transactions. Freedom of contract operates efficiently under a set of clear and certain default rules as positive law.

Contract law specifies two kinds of legal rules: default rules and mandatory rules. ${ }^{23}$ Transaction costs include costs associated with the legal system, including those imposed by formal legal rules, rights and duties

unknown origin."). For a review of the economics literature, which perhaps paints a more optimistic picture, see James E. Rauch, Business and Social Networks in International Trade, 34 J. ECON. LT. 1177 (2001).

21. See Ronald J. Mann, The Role of Letters of Credit in Payment Transactions, 98 MICH. L. REV. 2494 (2000).

22. See RICHARD A. POSNER, ECONOMIC ANALYSIS OF LAW 103 (5th ed. 1998).

23. The seminal work on the subject is Ian Ayres \& Robert Gertner, Filling Gaps in Incomplete Contracts: An Economic Theory of Default Rules, 99 YALE L. J. 87 (1989). 
produced in contracts, and costs associated with informal norms. ${ }^{24}$ In any contract setting, contracts are necessarily incomplete, and cannot cover every contingency. It is efficient to maintain gaps in contracts, and rational contract parties rely on the law to fill gaps with default terms where the actual costs of filling gaps exceeds the expected costs of filling them. Conversely, contract parties will fill gaps when the actual costs of filling gaps is less than the expected costs of leaving gaps. The expected costs of gaps are determined by multiplying the probability of ex post loss by the costs of filling the gap. ${ }^{25}$

International default rules have the potential to decrease transaction costs and facilitate exchange. Many advantages exist to having a single set of off the rack international default terms to govern international contracting. In the rational calculus for engaging in gap filling in an international transaction, contract parties will specify more complete international contracts than they would, ceteris paribus, if they were contracting domestically. Because of information and monitoring problems inherent in contracting at long distances across borders, the probability of loss will be higher, ceteris paribus, than in local contracting, thus making more complete contracts rational. Parties will be uncertain, moreover, as to which default rules will apply to the transaction. In an international transaction, what are the gap fillers "the law" specifies? In the absence of an international convention to furnish default rules or an effective choice of law clause in the contract, the answer to this question is uncertain. ${ }^{26}$ Simply saying that a default rules analysis should be used begs the question of which set of default rules is to apply to the transaction in question. As a result of this uncertainty in the law, contract parties must necessarily fill more gaps than in a situation where clearly only the law of a single jurisdiction applies. Moreover, domestic legal systems may fail to specify default rules in areas where special problems arise in international transactions. Even if parties could predict that a particular local law applied

24. See FUROBOTN \& RICHTER, supra note 19, at 43 (stating similar classification).

25. See Ayres \& Gertner, supra note 23.

26. The reason why reliance on choice of law clauses is unsatisfactory is explained infra notes 34-50 and accompanying text. The economics of default rules has not yet been systematically applied to international contracting, where more than one legal system is involved. See Michael Whincop \& Mary Keyes, Putting the 'Private' Back into Private International Law: Default Rules and the Proper Law of the Contract, 21 MELBOURNE U. L. REV. 515 (1997). "Most research analyzing the properties of default rules assumes a domestic or national setting." Id. at 516 . 
to them, and could predict the content of that law, learning and complying with an unfamiliar rule of law increases the costs associated with reaching agreement. This is true even if the governing law turns out to work well for the particular transaction. These additional costs may include increased lawyer fees and opportunity costs associated with time and effort.

The lack of a common legal infrastructure in Europe may result in increased transaction costs associated with gap filling. The submission of the International Chamber of Commerce to the European Commission concerning the request for comments on the possibilities for producing a common set of European contract law principles explains:

Due to divergences in European contract law, it is necessary to use different standard contracts in each Member State, which in turn makes it impossible to use the same business model for the whole European market. It is not possible to use the same operation for claims from unsatisfied customers since contract law in Europe differs so significantly across Member States. It should also be emphasized that this creates great uncertainty as to what contract law applies in a given situation in Europe which may discourage and prevent businesses from even trying to reach out to the whole Internal Market. ${ }^{27}$

The need to fill relatively more gaps in cross-border transactions than in domestic transactions may have an adverse effect on small businesses for which high transaction costs are prohibitive and cannot be spread across many transactions. ${ }^{28}$ Add to this the problem of small states with small markets-there is a systemic effect to all of this-traders in small states with small markets suffer disproportionately because they have to engage in more cross-border contracting, all things being equal, than their counterparts in large states with large markets. ${ }^{29}$ For a common market, legal divergence makes little sense, or at least substantial legal divergence of the sort that exists in Europe but which does not exist in the United States.

27. International Chamber of Commerce Comments, Communication from the European Commission to the Council and the European Parliament on European Contract Law, $\operatorname{COM}(2001) 398$ final, Oct. 15, 2001, available at http://europa.eu.int (accessed by selecting "The European Union On-Line," "Institutions" then "European Contract Law") (last visited June 8, 2003).

28. Id.

29. Id. 
The elements of the documentary sales transaction themselves exemplify increased specificity in international contracts. The documentary letter of credit, bill of lading, bill of exchange and other documents are used much less frequently in domestic sale of goods transactions. Indeed, these documents are almost always considered to be unnecessary in a purely domestic context. These documents serve to fill in terms relating to payment and performance. In addition, although no empirical research has yet to be carried out on this question, at an intuitive level, it does seem that, all things being equal (when comparing similar sorts of contracts by price, quality and other non-institutional factors), the standard forms of buyers and sellers tend to be more detailed for cross-border transactions than for domestic transactions. ${ }^{30}$

The above analysis addresses the issue from the perspective of default terms. The costs of legal diversity in international transactions are exposed dramatically when we turn to mandatory terms in contracts. Mandatory rules regulate contract formation and performance. Some mandatory rules are found in contract law itself, such as rules relating to duress, undue influence, capacity to contract, and illegality. ${ }^{31}$ Mandatory rules from a variety of other sources apply to international business transactions, from antitrust and competition law, consumer law, bankruptcy law, customs law, health and safety law, environmental law, fair labor and employment legislation, securities and corporate law and so on. Compelling reasons exist for some level of commonality in many of these areas, each subject to its own economic logic. Mandatory rules that differ across jurisdictions may make the structuring of a transaction more difficult or even prevent it from going forward. A transaction easily accomplished under one legal

30. Perusing the practical guides on how to draft international contracts provides the intuition. See, e.g., ALBERT H. KRTIZER, INTERNATIONAL CONTRACT MANUAL (1991) (regarding contract checklists).

31. Other examples come from secured transactions law and trust law. It is relatively simple in Anglo-American jurisdictions to include after-acquired property clauses in contracts, under which a creditor can take security in property the debtor acquires in the future. Commercial law in civilian regimes tends to be hostile to such arrangements. Neil B. Cohen, Harmonizing the Law Governing Secured Credit: The Next Frontier, 33 TEX. INT'L. L. J. 173, 176-177 (1998). As well, trust arrangements, vital to financial transactions, are not easily simulated in civil law. UGO MATTEI, COMPARATIVE LAW AND ECONOMICS, 147-48(1997); John Langbein, The Secret Life of the Trust: The Trust as an Instrument of Commerce, 107 YALE L. J. 165, 165-66 (1997). 
regime may be difficult, uncertain, or unduly expensive in another regime. ${ }^{32}$ Some of the more compelling reasons for common legal rules in these fields have to do with mitigating the collective action problems associated with states producing local laws to benefit their own residents but which actually result in welfare losses regionally or globally. ${ }^{33}$ When such welfare reducing diversity exists, transacting parties may structure choice of law contractually to reduce their own costs, but externalize those costs to third parties. Or, the weaker party in the transaction may bear a disproportionate burden. Outside of the EU, governments have made little progress in unifying mandatory rules.

\section{b. Contractual Choice of Law}

A common argument made in opposition to unification is that the choice of parties should be maximized by having legal diversity or competition among legal systems. ${ }^{34}$ The argument is that contract parties would somehow be better off if they have the freedom to choose the proper law of the contract from a menu of competing domestic legal systems. ${ }^{35} \mathrm{~A}$ contractual choice of law clause is a gap filler-a default term that contract parties use to fill a gap in the contract. The gap the parties fill is the absence of a common legal system. A contractual choice of law approach has negative consequences from the standpoint of both efficiency and distribution. Contractual choice of law as an alternative to international rules can work so long as certain restrictive conditions are met: (1) it is possible to Coasian bargain over the choice of law, (2) the parties do not evade efficient mandatory rules, and (3) the distributional consequences

32. See supra note 31.

33. See Andrew T. Guzman, Antitrust and International Regulatory Federalism, 76 N.Y. U. L. REV. 1142, 1143-46 (2001); Lucian Ayre Bebchuk \& Andrew T. Guzman, An Economic Analysis of Transnational Bankruptcies, $42 \mathrm{~J}$. L. \& ECON. 775 (1999).

34. Stephan, Futility of Unification, supra note 4, at 744.

35. Id. Stephan asserts:

We ought to spend less time drafting rules to govern the substantive rights and duties of persons engaged in a transaction, and more on devising ways to encourage states to facilitate contractual choices made by parties in the course of transactions and in encouraging states to reveal how they propose to deal with private disputes arising out of international commerce.

Id. 
resulting from Coasian bargaining are not repugnant to the sense of justice of the vast majority of persons if they were asked to evaluate the faimess of the transaction. Conditions one and two are examined in section ii below; condition three is examined in section iii. The basic point is that legal diversity does not work in all cases. It is not a universal solution.

\section{i. Questioning the Question}

As a threshold matter, the dichotomy of unification versus diversity is not nearly as stark as often proposed, and indeed may be a false choice. The framing of the question whether law is unified or not runs the risk of missing the essential elements of how law is produced and how it evolves. Even common law jurisdictions such as England have been subject to "codifying" or "rationalization" by Blackstone, Coke and others. ${ }^{36}$ There has always been a cross-fertilization between the dominant western legal traditions. ${ }^{37}$ When the common law receives an idea from the civil law, that idea comes from a tradition that places significant value on the unifying rationale of the jus commune. In the common law tradition, stare decisis serves as a unifying principle analogous to the jus commune. Also within the common law tradition, restatements promote unification. US courts have relied upon restatements liberally. Restatements in the twentieth century supplanted the nineteenth century practice of US courts looking to English case law for guidance. ${ }^{38}$ Restatements have been influential even outside of the United States. ${ }^{39}$ The question could more properly be reframed as not whether law should be unified or not, but what kind of

36. See Robert C. Berring, Legal Research and the World of Thinkable Thoughts, 2 J. APP. PRAC. \& PROC. 305 (2000); Gunther A. Weiss, The Enchantment of Codification in the Common Law World, 25 YALE J. INT'L L. 435, 437, 442 (2000).

37. See James Gordley, The Common Law in the Twentieth Century: Some Unfinished Business, 88 CALIF. L. REV. 1815, 1817 (2000) (arguing that the common law should borrow some private law concepts from the civil law); Ugo Mattei, Why the Wind Changed: Intellectual Leadership in Western Law, 42 AM. J. COMP. L. 195, 203-09 (1994) (arguing that intellectual leadership in western law shifted from Germany to the United States in the post war period) [hereinafter Mattei, Why the Wind Changed].

38. See, e.g., CA. CIVIL CODE $§ 22.2$ (1982) ("The common law of England, so far as it is not repugnant to or inconsistent with the Constitution of the United States, or the Constitution or laws of this State, is the rule of decision in all the courts of this State.").

39. See supra note 3. 
unification is preferred-at what level-domestic or international, and what sorts of institutions-courts, legislators or scholars-should undertake unification. The law in action does not present the question of "diversity versus unification" as an either-or proposition.

The analysis of legal diversity using only the tools of rational choice, if taken to its logical end, is a tautology because it leads to the conclusion that total decentralization is best because it maximizes choice for the parties because they can write their own contracts. But parties cannot write their contracts without law except perhaps in the most limited of ideal circumstances, in which transaction costs are at or near zero. The chains in the logic simply do not work: legal diversity is preferable to unification because it produces jurisdictional competition in which countries will compete to supply the best laws. ${ }^{40} \mathrm{Within}$ countries themselves, we can extend the competition to sub-central units, such as state courts and state legislatures in the United States. We could further decentralize to local government, and eventually to a situation where total decentralization prevails. Total decentralization means no law external to the parties, an untenable state of affairs because there would be no legal diversity anymore and no choice, because there would, uniformly, be no law anywhere. Besides the logical difficulties with too strong a concept of legal diversity, there is the practical problem of transaction costs, which is more properly discussed in section ii below.

In the end, the attraction of unification is its potential to provide incentives for people to make contract choices based on non-institutional factors such as the price and quality of goods and services in different jurisdictions, rather than on institutional considerations such as the law and courts of the jurisdiction in question. Do firms and consumers in the United States make contract decisions based on the relative superiority of Pennsylvania law over Ilinois law? Unification is an essential prerequisite for economic integration in common markets.

\section{ii. Efficiency Concerns About Contractual Choice of Law}

It is doubtful that contractual choice of law is efficient in the large majority of transactions that international traders enter. Contractual choice of law presupposes low transaction costs in bargaining toward an efficient

40. The efforts of jurisdictions themselves to engage in jurisdictional competition have to be put under the scrutiny of public choice theory and political economics. Countries have incentives to produce rules that favor their own residents. Guzman, supra note 33. This question is dealt with in Part II below. 
choice of law for a contract. It at least implicitly assumes a vigorous application of the Coase Theorem, in low-to-zero transaction cost conditions, in which parties can bargain to an efficient result. Choice of law is a solution only where the parties have a low cost ability to obtain information about the laws of the relevant jurisdictions. In this sense, there is some question begging in the analysis of legal diversity proponents, since increased levels of congruence between legal systems decreases the transaction costs of learning about another legal system.

If parties could indeed bargain to an efficient selection of legal rules to govern their transaction, then their menu of choice is invariably increased if they could also choose from an international set of rules, which may be designed to reflect majoritarian rules applicable to international transactions. Rules that are meant to be transnational or trans-state can actually increase choice. The experimentation argument applies to restatements and conventions as well as to experimentation among several domestic states. ${ }^{41}$ These rules can be formal law, such as the Convention on the International Sale of Goods, ${ }^{42}$ or compilations of nonbinding rules, such as the UNIDROIT Principles of International Contracts. ${ }^{43}$ Nonbinding rules increase choice when parties choose to resolve disputes through arbitration rather than through the domestic courts of a particular forum.

If transaction costs are high or externalities are present, Coasian bargaining may not be possible, and the "Hobbes Theorem" applies-law matters. ${ }^{44}$ Choice of law through contract either does not occur or occurs and is inefficient because the parties either do not have adequate information to make an informed choice or do not internalize the full social costs of the choice of law. In such situations, parties should have the confidence to be able to rely on a proper set of default rules. Here we are back to our default rules analysis. What sorts of default rules are preferred? Majoritarian or market mimicking rules? Information forcing penalty defaults? In the absence of unification, conflict of laws rules would supply

41. There are many articulations of this argument. See, e.g, Stephan, Futility of Unification, supra note 4, at 792-93; Ribstein \& Kobayashi, supra note 19, at 3132.

42. United Nations Convention on Contracts for the International Sale of Goods, USCS International Agreements (1995), available at http://www.cisgonline.ch/cisg/conv/convuk.htm. (last visited May 8, 2003).

43. UNIDROIT Principles of International Commercial Contracts (1994), available at http://www.unidroit.org/english/principles/pr-main.htm (last visited May 6, 2003).

44. See Robert Cooter, The Cost of Coase, 11 J. LEGAL STUD. 1 (1982). 
an answer. Conflict rules are not tailored to answer such questions, and the institutional problems in devising them to do so seem insurmountable. Conflict rules would have to compel domestic courts of multiple jurisdictions and arbitrators to do the following:

1) Assess what sort of rule should apply to the dispute, consistently with economic theories on default rules; and

2) Direct the decision maker to the right jurisdiction to supply the rule.

Moreover, because the transaction costs were high enough to preclude contractual choice of law, then they are likely high enough to preclude contractual choice of forum. Choice of forum rules thus would have to point the parties to the forum that would do the above two tasks. This asks too much of conflict principles.

Additionally, choice of law and forum clauses and arbitration clauses may result in the application of inefficient mandatory law. The parties to a transaction will bargain towards the choice of rules and a forum to maximize their individual share of the surplus of the transaction. They are not interested in efficiency. Parties do not choose to opt out of mandatory law because it is inefficient. Indeed, they may be trying to circumvent efficient law, such as antitrust or competition law that promotes efficiency in their product markets. ${ }^{45}$ They have no concern for the effects of their choice on third parties, or absent repeat play the other party to the transaction. Contract parties can select either inefficient courts or inefficient arbitral panels. Courts tend to apply their own mandatory law regardless of efficiency concerns. Courts do not base public policy decisions about the application of mandatory law on efficiency. They take what legislatures do as givens, and may insist that mandatory rules be applied even if they are inefficient. Arbitral panels generally apply the mandatory law the parties specify in a choice of law clause, or no mandatory law if the parties expressly exclude particular laws from application in the event of a dispute under the contract. ${ }^{46}$

45. Antitrust and competition law would actually have to result in efficiency improvements. See THE CAUSES AND CONSEQUENCES OF ANTITRUST: THE PUBLIC Choice PersPeCtrve (Fred S. McChesney \& William F. Shughart eds., 1995) (examining problems of interest group capture of antitrust law).

46. Alan REDFERN \& MARTIN HuNTER, LAW AND PRACTICE OF INTERNATIONAL COMMERCLAL ARBITRATION 93-128 (3d ed. 1999). One possible institutional mitigation is that in actions for enforcement of judgments or arbitral 
Finally, in international transacting characterized by choice of law as the dominant method of selecting legal rules, developing countries have no opportunity to develop their legal systems. International contracts of significant size and importance, where one of the contracting parties is foreign, will likely continue to specify New York or English law and arbitration or foreign courts. International conventions, model laws and restatements provide "off the rack" rules for developing countries to adapt their own laws and to develop indigenous legal capacity, which will have spillover effects to other parts of the legal system. ${ }^{47}$

\section{iii. Distributional Concerns About Contractual Choice of Law}

In a situation of information asymmetries, legal diversity makes the more knowledgeable party better off. This party may be the more legally sophisticated, the larger company, or the merchant instead of the consumer. The issue from the standpoint of strategic behavior is who gets the larger share of the surplus from a transaction. We may not like the result from the standpoint of distribution. The problem is exacerbated when transactions concern "legal products," such as insurance policies, where consumers have to choose between different products based on different law. Such products are costly for consumers to evaluate ${ }^{48}$ To use a European example, how does a consumer in England evaluate an insurance policy offered on a website of an Italian insurance company?

Legal diversity has a tendency to shift costs to weaker parties. To understand this, consider the Rome Convention, which in general terms provides that unless the parties otherwise specify, consumer contracts are

awards, the enforcing court can refuse to enforce the award if enforcement would violate the public policy of the state in which the enforcing court is situated. In situations where the enforcing and deciding tribunal differ, in effect, two forums have the opportunity to apply their mandatory rules.

47. See John Linarelli, The WTO Transparency Agenda: Law, Economics and International Relations Theory, in PUBLIC Procurement: The ConTINuInG REVOLUTION 235 (Sue Arrowsmith \& Martin Trybus eds., 2003) (discussing law reform and capacity building in developing countries in the context of public procurement law).

48. See Jürgen Basedow, The Case for a European Insurance Contract Code, 2001 J. BUS. L. 569 (2001). To generalize, this reasoning would come into play whenever a contract exists as a product, rather than as a consensual meeting of the minds. See Jane Margaret Radin, Humans, Computers and Binding Commitment, 75 IND. L.J. 1125 (2000). 
governed by the law of the consumer's habitual residence, and in no circumstances can choice of law deprive the consumer of the protection of the laws of her country of residence where that law is more favorable. ${ }^{49}$ Some European firms, notably in financial services, have complained about these rules, arguing that they must bear the costs of local regulation and that this increases their costs and therefore decreases exchange opportunities open to consumers. ${ }^{50}$ These firms would prefer country of origin regulation, but country of origin regulation simply shifts costs to consumers. Firms are in a better position to comply with the various laws of the EU member states, particularly as those laws are increasingly harmonized through directive and regulation, than are consumers in having to become familiar with the laws of the member states of the firms from which they buy goods and services. This is a classic adverse selection problem: European consumers lack the confidence to purchase from firms located in other EU member states because they do not know what they are buying - the transaction costs of distinguishing good from poor quality promises are prohibitive. Choice is question begging: it makes little sense unless laws have already substantially converged.

\section{Unification and Path Dependence}

In this section, I examine the work of two leading comparativists, Pierre Legrand and Ugo Mattei. They have important things to say, particularly about proposals for a European civil code and private law unification. Their work may be placed in an economic context by using the concept of path dependence. Legrand, not a lawyer-economist, is an avid opponent of unification. I critique Legrand by suggesting that his principal objection to unification can be cured by unification. On the other hand, economics explicitly influences Mattei's work. Mattei supports unification skeptically. His basic finding is that the European countries have to find a common core of legal principles before any meaningful unification can occur. These two scholars support unification in complementary ways, although Legrand

49. Convention on the Law Applicable to Contractual Obligations, art. 5, June 19, 1980, O.J. (L 266) 1, available at http://www.europa.eu.int/eur-lex/en/lif/dat/ 1980/en_480A0934.html (last visited Mar. 20, 2003).

50. See, e.g., London Investment Banking Association Comments, Communication from the European Commission to the Council and the European Parliament on European Contract Law, COM(2001) 398 final, Nov. 28, 2001, available at http://www.europa.eu.int/comm/consumers/cons_int1/safe_shop/fair_ bus_pract/cont_law/comments/2.3.4.pdf(last visited May 6, 2003). 
must first be reinterpreted in an economic context in order to convert his argument against unification to an argument for unification.

Legrand's thesis is that the common law and the civil law are fundamentally incompatible, and that the "epistemological chasm" between the two traditions is so deep that to pursue the unification of European private law would do violence to the common law tradition. ${ }^{51} \mathrm{He}$ contends that the ideal conceptions of the civil law tradition, based on universalism, rationalism, systematization and formal logic ${ }^{52}$ have already been projected into the legal style of the European Union, which projects itself as a "universally operational system of comprehensive and coherent rules." 33 This way of conceptualizing a legal system is very different from the "tradition of working disorder" of the common law. ${ }^{54}$ Legrand explains the problem as follows:

Since the common law mind ... does not think in terms of systems, codes, categories and rules, the implementation of civilian assumptions in the common law world via the vehicle of European Community law would effectively call upon common law lawyers to transfer their basic epistemological loyalties to the civilian model-an intellectual formation which remains fundamentally inconsonant with their conception of justice. The communion assumed to be epitomised by a European civil code would in effect represent, beyond the sum of words, the excommunication of the common law way of understanding the world and the relegation to obsolescence of its particular insights. The repudiation of the common law would also leave common law lawyers at odds with the culture they inhabit which would continue to articulate its moral inquiry according to traditional standards of justification. In effect, common law lawyers would find themselves compelled to surrender cultural authority and to accept unprecedented effacement within their own culture. ${ }^{\text {ss }}$

Legrand argues that the civilian tradition is not universal. He argues that

51. See Legrand, Are Civilians Educable?, supra note 5, at 221.

52. See id. at 216.

53. Id. at 222.

54. Id. at 220 (citing Tony Weir, The Common Law System, in 2 INTERNATIONAL ENCYCLOPEDIA OF COMPARATIVE LAW: LEGAL SYSTEMS OF THE WORLD: THEIR COMPARISON AND UNIFICATION 2 (1981)).

55. Id. at 222 (citations omitted). 
it is "historically contingent" particularised and localised perspective on legal knowledge." to Legrand, the civilian and common law traditions are "epistemic peers," neither inferior nor superior to the other, even though the common law tradition prevails in a minority of jurisdictions - a fact which he characterizes as "strictly irrelevant." ${ }^{\text {" }}$ Legrand concludes that " $[t]$ he key to the success of the European venture simply cannot lie, therefore, in propounding a norm of uniformity which does not account for the very real epistemological discrepancies arising between the civil law and the common law worlds." $" 99$

Mattei contends that the European states should adopt a European civil code if it decreases transaction costs..$^{60} \mathrm{He}$ contends that the "best transaction-cost reducing codification is the one that is able to verbalize and codify what there is already in common in the law of as many of the Member States as possible." Common Core Project at the University of Trento. Other European legal scholars have taken on similar projects, including Ole Lando, who directs the Commission on European Contract Law. ${ }^{62}$ In Europe, there is a movement to publish casebooks for a common law of Europe for use in law schools throughout Europe. It is unknown whether these casebooks will be widely-adopted. ${ }^{63}$

The ideas of Legrand and Mattei suggest that path dependence may produce obstacles to unification. Path dependence is a term used in legal theory, economics, evolutionary biology, and complexity theory to refer to the circumstances in which "an outcome or decision is shaped in specific and systematic ways by the historical path leading to it." ${ }^{.64}$ A more

56. Id.

57. Id.

58. Id. at 225 .

59. Id.

60. See generally Mattei, supra note 3; Ugo Mattei, The Issue of European Civil Codification and Legal Scholarship: Biases, Strategies and Developments, 21 HASTINGS INT'L \& COMP. L. REV. 883 (1998).

61. Mattei, supra note 3, at 539.

62. See generally, Legrand, Are Civilians Educable?, supra note 5, at 219. For a closer look at Ole Lando's project, see http://www.ufsia.ac.be/ estorme/ CECL.html (last visited Mar. 6, 2003).

63. See, e.g., CASEBOOKS ON THE COMMON LAW OF EUROPE: CONTRACT LAW (Hugh Beale et. al eds., 2002).

64. Oona A. Hathaway, Path Dependence in the Law: The Course and Pattern 
economically-oriented definition is that path dependence exists when efficiency outcomes in a time dynamic context "exhibit sensitive dependence on initial conditions." ${ }^{\circ 5}$ In other words, history matters. The result may be that "lock-in by historical events" occurs, meaning that inefficient outcomes may persist. ${ }^{66}$ The literature on path dependence is varied and inconsistent. The persistence of prior conditions indeed may be efficient, either today or when examined dynamically over time, or inefficient but not worth changing because the costs of change are greater than the benefits. ${ }^{67}$ The path dependence addressed here is what some have termed "third degree path dependence" or "strong-form path dependence," where prior conditions produce an inefficient path resulting in lock-in. ${ }^{68}$ In third degree or strong form path dependence, the benefits of change exceed the cost of change, but change does not occur. Collective action is necessary to counter the inefficiency of individuals operating in a privately optimal way that produces socially inefficient results. In the unification context, local courts and institutions are unable to coordinate and intervention at a higher level is needed to break the lock. Path dependence persists because of information costs, costs associated with cooperation or coordination, and costs associated with public choice. ${ }^{69}$

The obstacles that Legrand and Mattei identify indicate that path dependence blocks unification of the law for the same sorts of reasons. ${ }^{70}$ Legrand contends that unification is impracticable because the common law and the civil law have fundamentally different epistemologies-a contested proposition. ${ }^{71}$ Differing theories of knowledge in the two western traditions relate to what economists refer to as information costs and the costs of cooperation or coordination. An answer to Legrand's criticism is

of Legal Change in a Common Law System, 86 IOWA L. REv. 601, 614 (2001).

65. S.J. Leibowitz \& Stephen E. Margolis, Path Dependence, Lock-in and History, 11 J. L. ECON. \& ORG. 205 (1995).

66. W. Brian Arthur, Positive Feedbacks in the Economy, 262 SCl. AM. 92 (Feb. 1990).

67. See generally Michael P. Van Alstine, The Costs of Legal Change, 49 UCLA L. REV. 789 (2002) (focusing on the costs of changing law).

68. Liebowitz and Margolis use the phrase "third degree path dependence" while Roe uses the phrase "strong form path dependence." Liebowitz \& Margolis, supra note 65; Mark J. Roe, Chaos \& Evolution in Law and Economics, 109 HARV. L. REV. 641, 651 (1996).

69. See Roe, supra note 68, at 651-52.

70. See id.

71. See Legrand, Are Civilians Educable?, supra note 5, at 221. 
to do precisely what he opposes-promulgate common codes which would break the lock-in of local law. Common courts could interpret the common codes. Law has an expressive function; it does more than provide incentives. ${ }^{72}$ The common codes would lead to network effects which would promote common legal culture, thereby reinforcing the common formal legal rules expressed in the code. ${ }^{73}$ This approach to mitigating the problems contributing to path dependence is in essence what Mattei and other European legal scholars seek to do in the common core projects. The project of seeking out the common core for unification is a continual experiment in reducing transaction costs.

To understand why the costs relating to differing theories of knowledge are so important, consider the use of restatements by American courts. It would be incredulous to argue that restatements have failed to promote unification in American law. Restatements were possible because information costs associated with the legal system were low enough to permit unification through the use of restatements. In tum, restatements continue to produce a positive network externality that lowers information costs even further. The alternative, legal diversity and evolution through case law, may have produced similar results, although perhaps over a greater period of time. Whether restatements or case law alone would have been the more efficient approach-viewing efficiency dynamically, that is counting costs and benefits over multiple time periods-is an empirical question which is likely to be unanswerable with current analytical tools.

Legrand's counter no doubt would be that I have ignored one of his fundamental arguments: that the cultural imperialist force of jus commune ideals in the civilian jurisdictions will threaten the cultural identity of the minority common law traditions in Europe. Depending on what side they happen to be on in this debate, European legal entrepreneurs will either

72. See Lawrence Lessig, Social Meaning and Social Norms, 144 U. PA. L. REV. 2181 (1996); Cass R. Sunstein, On the Expressive Function of Law, $144 \mathrm{U}$. PA. L. REv. 2021 (1996); Cass R. Sunstein, Social Norms and Social Roles, 96 COLUM. L. REV. 903 (1996).

73. A network effect exists when "the utility that a user derives from consumption of a good increases with the number of other agents consuming the good." Mark A. Lemley \& David McGowan, Legal Implications of Network Economic Effects, 86 CAL. L. REV. 479, 483 (1998) (citing Michael L. Katz \& Carl Shapiro, Network Externalities, Competition, and Compatibility, 75 AM. ECON. REV. 424 (1985)); see also William J. Kolasky, Network Effects: A Contrarian View, 7 GEO. MASON L. REV. 577 (1999). In essence, a good becomes more valuable as more people use it. 
promote diversity to preserve power, or unification to establish power. These sets of issues relate to the problem of public choice which will either contribute to path dependence and the persistence of legal diversity, or have the opposite effect of promoting unification even if it results in inefficiency. These situations are examined in the next Part because they have been the subject of a considerable research agenda using the tools of political economics. Moreover, beyond the economic analysis of unification, if unification extends beyond Europe, which it does in many instances, England and Wales, Northern Ireland and the Republic of Ireland should benefit from the considerable intellectual leadership in the common law tradition of the Commonwealth countries, notably Australia and Canada, and the United States, and any cultural imperialism coming from the Continent may be deterred. Still, some legal professionals associate unification with the loss of power and will try to stop unification even if it would improve the efficiency of the law.

The debates outlined here may seem similar to the nineteenth century debates between historicists and anti-historicists over European codification. ${ }^{74}$ The difference is the focus on efficiency and how the past may have produced an inefficient legal rule, which is locked in and too costly to modify. The nineteenth century debates about codification were philosophically centered; the twenty-first century debates focus on economics.

\section{THE Positive ECONOMICS OF THE UNIFICATION PROCESS}

\section{A. General Considerations}

Much of the criticism of unification is directed at concerns relating to the positive economics of the process by which various institutions produce unified bodies of rules. A political economist would assert that the above normative analysis presents an idealized situation, which has to be tested against how public and private legislatures actually make unified laws. Theorizing is an important thing to do, but ultimately the implementation of theoretically inspired law reform has to be in the realm of the practical. ${ }^{75}$

74. See KonRad ZWEIGERT \& HEIN KŌTZ, INTRODUCTION TO COMPARATIVE LAW 138-42 (Tony Weir trans., 3d ed. 1998); Mathias Reimann, Nineteenth Century German Legal Science, 31 B.C. L. REV. 837 (1990).

75. See Mattei, supra note 3, at 537 (using a transaction cost standard to assess). 
In law and economics, the test of whether unified law is better than diverse laws is whether it is an efficiency improvement. ${ }^{76}$ Efficiency improvements depend on institutions. A basic insight from political economics is that institutions matter because their characteristics affect the contents of legal rules. As a simple example, a rule of unanimity in a legislature will produce a different statutes than a rule of simple majority. How institutional rules such as voting, which are in themselves rules, affect the content of substantive rules and policies that a legislature or some other law making body produces is the subject of analysis of public choice, positive political theory and new institutional economics. All of the schools of thought can broadly be lumped into the subject of "political economy."

Political economics does not analyze the legitimacy of government, but rather its efficiency. The entire edifice of the political economy project is built around the assumption that the public interest model of government fails to accurately predict why laws are made or why public policy takes the content that it does. Whether a particular rule making body is elected is only one of a number of institutional features to be analyzed in understanding the incentives that individual members of the rule making body face. There is a market for votes, which affects the behavior of interest groups in seeking laws and of politicians in making them. ${ }^{78}$ The questions that political economists investigate go beyond whether the members of a particular body are elected, but how they are elected-majority rule, first past the post, proportional representation-and they also delve deep into questions of how voting along with other institutional considerations affect law making. Thus, one critique of private legislatures that can be dismissed at the outset is the complaint that the members of private legislatures are not elected. ${ }^{79}$

76. Id. at 538 .

77. Institutional economics has a broader focus, in that it more freely examines substantive rules as institutions, since much of the transaction cost analysis used in the prior part could be classified as new institutional economics. See FUROBOTN \& RICHTER, supra note 19 (analyzing the role of institutions in economic performance). The boundaries between the disciplines are fuzzy. For purposes of setting forth a toolkit on how to investigate the effects of institutional design of the substantive outcomes of public policy, I have lumped new institutional economics together with public choice and other process-focused approaches.

78. See JAMES BUCHANAN \& GORDON TULLOCK, THE CALCULUS OF CONSENT 283 (1962) (theorizing that the reason that special interest groups exist is, "their ability to promote and to further, through the political choice process, the particular functional interests represented").

79. See Stephan, Futility of Unification, supra note 4, at 752. 
Much of the critique of private law unification has been directed against what are known as "private legislatures." ${ }^{80}$ No definition of the phrase exists, but the literature identifies a few institutional features of the various bodies under investigation. The few characteristics that private legislatures share are: they are not "official" government bodies, in the sense that their membership is not elected, but their membership may be appointed by elected officials or bureaucrats, and in some cases the organization is part of a legally recognized international organization. Private legislatures are said to engage in "technocratic" lawmaking, in that model laws, international conventions, restatements or codifications of customs are produced, often with the idea that a government might adopt the instruments produced. ${ }^{81}$ Many of the instruments that private legislatures produce, with the exception of restatements and codifications of customs, have to be adopted or implemented by an official law making body, such as a domestic legislature, in order to become effective. Other than these very general characteristics, private legislatures have diverse institutional structures. For example, the International Chamber of Commerce, a body whose membership is comprised of private firms, is different institutionally from UNCITRAL, whose membership is comprised of UN member governments, and both are different from the American Law Institute in the important institutional detail that produces incentives for the stakeholders of these organizations.

The critics of private legislatures make much of the kinds of rules that private legislatures make, classifying the rules into two kinds: Model 1 rules, which are objective, bright line rules such as speed limits; Model 2 rules, which are more abstract rules vesting discretion in a decision maker such as a judge, and Model 3 rules, which are a middle ground or combination of model 1 and 2 rules. ${ }^{82}$ They contend that when interest group power is strong in a private legislature, the legislature will produce Model 1 rules in favor of the powerful interest group. In other cases, private legislatures will produce Model 2 and 3 rules ${ }^{83}$ While this model

80. See supra note 4.

81. Id.

82. Schwartz \& Scott, supra note 4, at 605.

83. According to Stephan, Futility of Unification, supra note 4, at 759-60:

Summarizing the argument, the new work on the political economy of private lawmaking by bodies of technical experts predicts that: (1) many rules will vest considerable discretion in decisionmakers, such as judges, rather than specifying outcomes that must flow from described circumstances; (2) those rules that are precise and constrain decisionmakers will largely reflect the preferences of particular interest 
does much to expose the institutional weaknesses in private legislating, it cannot be cast as a general model of uniform lawmaking. This is particularly so in the international context, since the basic research on private legislatures examined the workings of the NCCUSL and the ALI in producing the US Uniform Commercial Code. There are some general concerns about the model. The qualities of legal rules made by private legislatures seem no different than the qualities of legal rules made by public legislatures. Moreover, the model rules typology is of doubtful utility because it oversimplifies the kinds of rules that legislatures make. Complex commercial legislation usually combines all three kinds of rules, and it is often difficult to separate out which rules fall within a particular category. In other words, if the entire products of legislatures were to be evaluated, the conclusion would be overwhelmingly Model 3. In addition, whether a rule is Model 1 or Model 2 may simply affect which institution decides the content of the rule and who bears the costs of filling in that content. $^{84}$ Given that judges may be more immune to interest group pressures than legislators, Model 2 rules may be preferred for most legislation and self-executing treaties. If this is the case, the complaints about the lack of detailed Model 1 rules in the CISG, for example, lose vitality. ${ }^{85}$

Perhaps the most significant problem with model-building to further our understanding of law unification is the problem with model building generally: it ignores institutional nuance and complexity, some of which may affect the content of the legal rules resulting from the lawmaking process. The three case studies set forth below draw inquiry to the institutional complexity of the uniform law process. The case studies offer at least two insights. First, the institutions that produce uniformity may be more efficiency maximizing than domestic lawmaking bodies, and domestic interest groups may thwart efficiency improvements in the law. The first two case studies show these basic points. Second, attempts to stop governments from engaging in uniform lawmaking is akin to having the government try to set price and quantity for any product: governments and

groups, such as banks, broadcasters, common carriers, etc.; and (3) the rules taken as a whole will not constitute a clear and definite departure from the status quo, because interest groups will enjoy considerable Id. success in blocking any rules that encroach on their particular preferences.

84. See Louis Kaplow, Rules Versus Standard: An Economic Analysis, 42 DUKE L.J. 557 (1992).

85. See Stephan, Futility of Unification, supra note 4, at 774. 
interest groups will find ways around prohibitions so that the demands for unification will be met. Law harmonization in the European Union exemplifies this basic insight, and it is the subject of the third case study. The bottom line is that we have much more work to do to really understand how multiple institutions interact in uniform lawmaking.

B. Domestic Interest Groups Thwarting International Improvements: The Capture of the Domestic Lawmaking Process

This section sets forth two case studies, the first from the United States and the second from the United Kingdom. Given the prominence of these two states in the development of commercial law in the past few centuries, case studies from them would seem to be appropriate. The first case study examines the efforts of the United States (and other countries) to revise copyright law to deal with the digital environment. The relevant international instrument is the World Intellectual Property Organization (WIPO) Copyright Treaty ${ }^{86}$ and the relevant US implementing legislation is the Digital Millennium Copyright Act (DMCA) ${ }^{87}$ For measures designed to prevent the circumvention of technological measures used to protect copyrighted work, experts preferred a balanced approach of legal standards based on Model 2 characteristics. Powerful interest groups at the US domestic level, however, were able to thwart the implementation of Model 2 rules, in favor of Model 1 rules in their favor. The second case study explores the question why the United Kingdom (UK), a major trading nation, has not ratified the CISG. A powerful set of facts come together to suggest that the reason is that interest groups, in particular the British legal establishment, have thwarted UK acceptance of the CISG. The case studies inform us that the theories offered to explain how private legislatures influence the international lawmaking process is incomplete and at best only partly predictive.

1. The WIPO Copyright Treaty and the US Digital Millennium Copyright Act

The role of copyright law in the digital environment is one of the most challenging legal problems of the twenty first century. The rules of

86. WIPO Copyright Treaty, Dec. 23, 1996, available at http://www.wipo. org/eng/diplconf/distrib/94dc.htm (last visited Mar. 6, 2003).

87. Pub. L. No. 105-304, 112 Stat. 2860 (Oct. 28, 1998) (codified at scattered sections of 17 U.S.C. (Supp. IV 1998). 
copyright have an important role in allocating the distribution of the surplus in any transaction involving an information good in which rights in copyright exist. In the realm of creative works, copyright law sets the rules of engagement in the classic battle between rights holders and users. Copyright law faces a "digital dilemma." ${ }^{88}$ Digital technology makes it possible for users of music, videos and books to make unlimited numbers of perfect copies in digital form. The Internet facilitates the distribution of digital works around the world at the speed of light at near zero marginal cost. But digital technology also makes it possible to control copying and distribution of information goods to a degree unattainable in the past. Rights holders can use encryption, trusted systems and digital watermarking technology to preserve existing markets for their works and also to create new markets. ${ }^{89}$ Digital technology has "the potential to demolish a careful balancing of public good and private interest that has emerged from the evolution of U.S. intellectual property law over the past 200 years." ${ }^{90}$

Rights holders, mainly the distributors of recorded music, video programs and books, but also artists, actors and authors, form the interest groups that want strong copyright protection. ${ }^{91}$ Rights holders have a vision of the Internet resembling cable or satellite television, a pay-per-use approach. Users of digital information, in contrast, form the interest groups that want weak copyright protection. They have a vision of the Internet in which the public interest carves out exceptions to copyright, based on fair use, freedom of speech and the First Amendment, and promoting the public interest through dissemination of innovations in science and technology. Rights holders prefer a strong system of rights designed to protect investments in innovation, while rights users prefer a system that asks

88. Raymond Shi Ray Ku, The Creative Destruction of Copyright: Napster and the New Economics of Digital Technology, 69 U. CHI. L. REV. 263, 263 (2001).

89. See id. at 264.

90. Id. (footnotes omitted) (citing NATIONAL RESEARCH COUNCIL, THEDIGITAL DILEMMA: INTELLECTUAL PROPERTY IN THE INFORMATION AGE (National Academy 2000); INFORMATION INFRASTRUCTURE TASK FORCE, INTELLECTUAL PROPERTY AND THE NATIONAL INFORMATION INFRASTRUCTURE, THE REPORT OF THE WORKING GROUP ON INTELLECTUAL PROPERTY RIGHTS 178 (Sept. 1995), available at http://www.uspto.gov/web/offices/com/doc/ipnii/ (last visited Mar. 6, 2003)).

91. The distributors of entertainment products-the record, movie and television companies-are primarily interested in strong copyright protection, as they make the lions share of the royalties for audio and visual products. $\mathrm{Ku}$, supra note 88 , at 264 . 
whether a right has a sufficient social value to deserve protection. ${ }^{92}$

Owners of intellectual property have two ways to protect their property: through law and through technology. ${ }^{93}$ These methods are not necessarily substitutes; they are more in the nature of complements. Technological means themselves produce their own dilemma. For every technological advance to improve the protection of intellectual property on the Internet, someone out there is trying to circumvent that technology. In the words of Gene Kan, the developer of Gnutella, ${ }^{94}$ in a U.S. Senate Judiciary Committee hearing, "[p]rotection schemes seldom work." 95 Kan continues: "If laws are enacted against these technologies, the ensuing replacements for these technologies would only be more difficult, if not entirely unfeasible, to police. This is only the beginning." ${ }^{\prime 26}$ Thus, as the argument goes, a combination of law and technology is needed to protect intellectual property on the Web.

Governments have supplied laws to rights holders to prohibit circumvention of technological measures designed to protect intellectual property in digital form, and to prohibit the manufacture and distribution of devices to circumvent such technological measures. At the international level, nearly 160 governments signed the WIPO Copyright Treaty. ${ }^{97}$ The Treaty provides an important set of international norms on digital intellectual property and electronic commerce. The Treaty contains a number of Model 1, 2 and 3 rules.

One Model 2 rule is found in Treaty Article 11, which prohibits the circumvention of technological measures designed to protect copyrighted work. The Treaty requires countries to provide "adequate legal protection and effective legal remedies against the circumvention of effective technological measures" that copyright owners use to protect their works

92. Id. at 265.

93. See LAWRENCE Lessig, Code AND OTHER LAWS OF CyBERSPaCe 122 (2000) (regarding law and fences).

94. Gnutella is a music sharing system similar to Napster but without a central file server to host directories.

95. Forum: Hearing Regarding the Future of Intellectual Property in the Digital Age Using Music as an Analog for All Types of Intellectual Property: Hearing Before the Senate Judiciary Committee, 106th Cong. at 9 (2000) (statement of Gene Kan, Developer of Gnutella).

96. Id. at 10.

97. See WIPO Copyright Treaty, supra note 86. As of February 25, 2002, thirty-four states have ratified the Treaty. The Treaty goes into effect three months after thirty states ratify or accede to it. $I d$. at art. 20 . 
against infringing uses. ${ }^{98}$ Copyright experts contend that the Treaty sets the proper balance between the rights of copyright owners and users. ${ }^{99}$ Surely the Treaty, like any other international instrument, would have to be subjected to public choice scrutiny to get a clearer assessment of this contention.

The US government, apparently in response to industry pressures, used the opportunity to produce legislation designed principally around Model 1 rules favoring a particular industry. According to Samuelson, "[t]he flaws in the DMCA's anti-circumvention provisions do not derive from the treaty, but rather from the bad judgment of the Administration and the major copyright industry groups that urged adoption of overbroad rules in the DMCA." ${ }^{100}$ She continues:

Clinton Administration officials, bowing to the wishes of Hollywood and its allies, opted instead to support an unpredictable, overbroad, and maximalist set of anti-circumvention regulations. . . . It was, in short, not the needs of the digital economy that drove adoption of the anti-circumvention provisions in the DMCA. Rather, what drove the debate was high rhetoric, exaggerated claims, and power politics from representatives of certain established but frightened copyright industries. These groups seem to believe they are so important to America that they should be allowed to control every facet of what Americans do with digital information. They also seem to think they are entitled to control the design and manufacture of all information technologies that can process digital information. The DMCA caters to their interests far more than to the interests of the innovative information technology sector or of the public. ${ }^{101}$

98. Id. at art. 11.

99. See, e.g., Pamela Samuelson, Intellectual Property and the Digital Economy: Why the Anti-Circumvention Regulations Need to be Revised, 14 BERKELEY TECH. L.J. 519, 528 (1999) ("The WIPO Copyright Treaty is Good for the New Economy."); see also Neil W. Netanel, The Next Round: The Impact of the WIPO Copyright Treaty on TRIPS Dispute Settlement, 37 VA. J. INT'L L. 441 (1997); Pamela Samuelson, The U.S. Digital Agenda at WIPO, 37 VA. J. INT'L L. 369 (1997).

100. Samuelson, Intellectual Property and the Digital Economy, supra note 99, at 563.

101. Id. at 533. 
It is widely accepted that the DMCA anti-circumvention provisions are overbroad and create a serious imbalance between rights holders and users. ${ }^{102}$ The core of the DMCA's provisions on anti-circumvention is Section 1201(a). ${ }^{103}$ Section 1201(a) contains two sub-sections. Subsection 1201(a)(1) is the anti-circumvention provision and subsection 1201(a)(2) is the anti-device provision. ${ }^{104}$

Section 1201(a)(1) prohibits individuals from circumventing "a technological measure that effectively controls access to a work." 105 This section, although subject to seven specific and complex exceptions, is broad in scope. It enables rights holders to sue to stop others from circumventing technological measures, even if those technological measures themselves circumvent the carefully balanced limits that copyright law places on property rights in creative works. ${ }^{106}$ In addition, the DMCA imposes criminal penalties for willful violations. ${ }^{107}$ The bright line standard of subsection 1201(a)(1) is overbroad in several ways. The Act contains no exception for decryption activities designed to detect whether an encrypted work is itself infringing. ${ }^{108}$ The Act contains no exception to

102. See Jonathan Band, The Road to Napster: Internet Technology and Digital Content, 50 AM. U. L. REv. 363 (2000):

Of course, the danger, when you start building fences around ... copyright law, is that some of the very limitations and exceptions that are built into the copyright law get lost. That, of course, is the fundamental problem with the Digital Millennium Copyright Act.... there is no question that the copyright law is far more nuanced and contains far more exceptions than the Digital Millennium Copyright Act. The technological protections are much more rigid than the law they are intended to protect.

Id. at 372; see also Dan L. Burk \& Julie E. Cohen, Fair Use Infrastructure for Rights Management Systems, 15 HARV. J.L. \& TECH. 41 (2001); Glynn S. Lunney, Jr., The Death of Copyright: Digital Technology, Private Copying, and the Digital Millennium Copyright Act, 87 VA. L. REV. 813 (2001); David Nimmer, A Riff on Fair Use in the Digital Millennium Copyright Act, 148 U. PA. L. REV. 673 (2000); Samuelson, Intellectual Property and the Digital Economy supra note 99; see also Jessica Litman, Revising Copyright Law for the Information Age, 75 OR. L. REV. 19 (1996).

103. 17 U.S.C. $\$ 1201$ (a) (Supp IV. 1998).

104. 17 U.S.C. $\$ 1201$ (Supp IV. 1998).

105. Id.

106. 17 U.S.C. $\S 1201$ (c) (Supp IV. 1998).

107. 17 U.S.C. § 1204 (Supp IV. 1998).

108. Samuelson, Intellectual Property and the Digital Economy, supra note 99, at 543 . 
accommodate free speech and free press concerns. ${ }^{109}$ The Act contains no exceptions for fair use, archival copying, fixed duration and other limitations on copyright, and the courts thus far have declined to read such limitations into the Act. ${ }^{110}$ Rights holders, or for that matter, anyone who chooses to encrypt a creative work, can develop a much finer grained control of the work, releasing only pages at a time, or permitting only the review of a limited number of pages once or a limited number of times. ${ }^{111}$ The Act contains no exception to defeat technological measures that are designed to stop software from being used during a contract dispute. Licensees will always be in a weaker position because they cannot circumvent self-help measures the licensors might place in the software. ${ }^{112}$

Subsection 1201(a)(2) prohibits the manufacture, importation, distribution and "trafficking" of any technology or device that "(A) is primarily designed or produced for the purpose of circumventing ... (B) has only limited commercially significant purpose or use other than to circumvent . . or $(C)$ is marketed . . . with . . knowledge for use in circumventing" a technological measure. ${ }^{113}$ This "anti-device" provision has the potential to be extremely effective. The anti-circumvention provision requires individual suits against persons trying to circumvent a technological measure. ${ }^{114}$ The anti-device provision, however, bans the production and importation of decryption technology. ${ }^{115}$ Rights holders can target their legal actions against the relatively few providers of such technology rather than the relatively numerous users of it. ${ }^{116}$ According to Lunney, "If Section 1202(a)(2) is effective, decryption technology will never become available to ordinary consumers, and widespread private copying will never occur." 117

The pre-DMCA anti-device law, as set forth in Sony Corp. of America v. Universal City Studios, ${ }^{118}$ stands in stark contrast to subsection 1202(a)(2). In Sony, the Supreme Court held that a person was liable for

109. Id.

110. Lunney, supra note 102 , at $819-24$.

111. Id.; Samuelson, supra note 99, at 543-44.

112. Lunney, supra note 102, at 819-24; Samuelson, Intellectual Property and the Digital Economy, supra note 99, at 543-44.

113. 17 U.S.C. $\$ 1201(a)(2)(2000)$.

114. Lunney, supra note 102 , at 830.

115. 17 U.S.C. $\$ 1201$ (a)(2) (2000).

116. Lunney, supra note 102 , at 830.

117. Id. at 830-31.

118. 464 U.S. 417 (1984). 
copyright infringement if her device was not "capable of substantial noninfringing uses." 19 The DMCA standard is plainly broader than the Sony standard because it bans technology having significant lawful uses. Culpability, moreover, turns on the manufacture or sale of circumvention technology alone-it does not matter for civil and criminal liability even if every single person who used the technology did so for a legitimate purpose. ${ }^{120}$

The DMCA provisions are so overbroad that commentators have been graphic in their condemnation. Reminiscent of Gilmore's prediction about contract law, Lunney asserts, "Copyright is dead. The Digital Millenium Copyright Act ... has killed it."121 Lunney's thesis is that the DMCA eliminates the public interest element from copyright law, converting it into a law designed merely to protect monopolies. ${ }^{122}$ Samuelson and others as well are harsh in their condemnation of the DMCA. ${ }^{23}$

The DMCA creates the situation in which an international treaty, under the auspices of an international organization, promulgated a Model 2 rule, largely found to be sufficient upon which to balance the diverse interests dealt with in copyright law, which was only to be supplanted by domestic implementing legislation that was essentially hijacked by lobbying groups reflecting the interests of Hollywood. Samuelson asserts that an improved DMCA would contain a Model 2 rule as a general purpose or "other legitimate purposes" exception to the anti-circumvention provision, which would allow courts to adapt the law flexibly in the common law process. ${ }^{124}$ She also recommends that the anti-device provision resemble a narrower Sony standard because persons cannot rely on the exceptions to the anticircumvention provision if they cannot obtain the decryption technology to exercise their rights under an exception. ${ }^{.25}$

This case study shows the interaction of international and domestic rules, and how domestic legislatures can scuttle improvements in the law, or at least use implementing legislation as an opportunity to obtain new rules that are injurious to the public interest. In this instance, international law making created an opportunity for powerful interest groups to take

119. Id. at 442.

120. Lunney, supra note 102 , at $834-35$.

121. Id. at 814 .

122. Id. at 814-15.

123. See supra note 102.

124. Samuelson, Intellectual Property and the Digital Economy, supra note 99, at $543-44$.

125. Id. at $546-57$. 
action at the domestic implementing phase. What transpired tends to show that it is difficult to extend existing positive political theories on private legislatures into the international arena.

\section{The British Refusal to Ratify the CISG}

In his important article on the public choice aspects of the unification process, Stephan inquires why "the United Kingdom, the country with the oldest and richest body of case law governing international sales transactions (and a specialist court in London set up to apply it)" has refused to ratify the CISG. ${ }^{126}$ For over a decade, legal scholars and practitioners in the UK have debated the reasons for the lack of ratification. The British government did not favor ratification until 1997, when it announced that it was in favor of ratification. Since that time, the government has taken no parliamentary action to ratify the CISG. ${ }^{127}$ In the absence of rigorous empirical investigation, one can only speculate, although such speculation can be based on a strong dose of intuition. ${ }^{128}$ Some reasons have stronger intuitive appeal than others, particularly if one accepts the tenets of public choice. To maintain a consistent and coherent approach to applying public choice teachings, we cannot simply rely on public interest oriented arguments as the real reasons for the British choice not to ratify the CISG. In line with a public choice influenced approach, I divide the reasons for the failure of the UK to ratify the CISG into two categories: conventional or "official" reasons and reasons based on public choice analysis. This approach aligns with the legal realist conception of

126. Stephan, Futility of Unification, supra note 4, at 779.

127. Anette Gärtner, Britain and the CISG: The Case for Ratification-A Comparative Analysis with Special Reference to German Law, in PACE REVIEW OF THE CONVENTION ON CONTRACTS FOR THE INTERNATIONAL SALEOF GOODS (2001), available at http://www.cisg.law.pace.edu/cisg/biblio/gartner.html (last visited Mar. 20, 2003); Alison E. Williams, Forecasting the Potential Impact of the Vienna Sales Convention on International Sales Law in the United Kingdom, in PACE REVIEW OF THE CONVENTION ON CONTRACTS FOR THE INTERNATIONAL SALE OF GOODS(2001), available at http://www.cisg.law.pace.edu/cisg/biblio/ williams.html (last visited Mar. 20, 2003). The UK Department of Trade and Industry issued a consultation document in 1997 expressing the government's desire to ratify.

128. I asked the British Department of Trade and Industry for the documentation, and was promised that it would be forthcoming. I did not receive it. No freedom of information legislation is currently in force in the United Kingdom. 
distinguishing between formal and actual reasons for legal decisions.

In no way is the following analysis intended to impugn the motives of anyone involved in the British legal establishment. The opponents of unification are unquestionably sincere in their motives, putting forth positions for or against unification based on what they genuinely believe to be the advantages and disadvantages of unification. This should not deter, however, a public choice influenced analysis, which focuses on "as if" rationality and on actions rather than meaning and interpretation. ${ }^{129}$

\section{a. The Conventional Reasons}

The conventional reasons are well rehearsed and set forth in detail elsewhere. ${ }^{130}$ The most strident arguments are set forth in a short five-page article by Lord Justice Hobhouse in the 1990 volume of the Law Quarterly Review. ${ }^{131}$ Notably, the criticisms offer few examples of the problems the CISG creates, and indeed Justice Hobhouse offered none. The arguments, by Hobhouse and others, can be summarized as follows:

- The Convention excludes questions of contract validity and the passing of property, and thus too much is left to national law. ${ }^{132}$

- A good deal of international commercial litigation occurs in London and according to English law. It would be unwise "to abandon the known and internationally respected virtues of English law in favour of the uncertainties" of the CISG. ${ }^{133}$

- Laws should favor the interests of the commercial community, and what the commercial community needs is "certainty," which derives from legal institutions available in a given country and from municipal commercial law itself. ${ }^{134}$ Intemational conventions such as the CISG

129. See Martin Hollis, The Philosophy of Social SCIENCE 50-59 (1994).

130. See Barry Nicholas, The United Kingdom and the Vienna Sales Convention: Another Case of Splendid Isolation? (March 1993), available at http://www.cnr.it/CRDCS/frames9.htm (last visited Mar. 20, 2003).

131. J.S. Hobhouse, International Conventions and Commercial Law: The Pursuit of Uniformity, 106 L.Q. REV. 530 (1990).

132. Nicholas, supra note 130 (referring to an argument that Derek Wheatley Q.C. made in the The Times on March 27, 1990).

133. Id.

134. Hobhouse, supra note 131, at 532-33. Certainty is not a reason that most 
are "multi-cultural compromises between different schemes of law," which "introduce uncertainty where no uncertainty existed before" and which "lack coherence and consistency."

- English law is superior to international instruments such as the CISG. As Sir Roy Goode explains, "there are those who consider that English law in all its majesty is greatly superior to anything that could be devised at [the] international level." ${ }^{.136}$ For lawyers who accept this position, the English Sale of Goods Act, which was promulgated in 1893, "is the quintessence of perfection, and the notion that we might benefit from [the] CISG in any way at all is anathema." 137 Those who support the idea of English law as an international standard also support the argument that contractual choice of law provides the best approach to solving the problem of providing law in international commercial transactions. ${ }^{138}$

- There has been a lack of industry pressure in the UK for the law. ${ }^{139}$ The lack of political will to legislate "lawyer's law," combined with the scarcity of parliamentary time..$^{140}$

- The lack of interest in the United Kingdom to "service" domestic law leads to lack of inertia in ratifying international instruments. According to Goode, apart from the work of the Law Commission for England

American lawyers would offer as a primary reason against international unification, and even much less so to justify any particular legal rule. English legal scholarship still has strong positivist and conceptual formalist tendencies that were abandoned some time ago in the high end of American legal scholarship. To a U.S. lawyer trained in the vagaries of federalism, moreover, certainty is an unrealistic goal, indeed a "utopian" quest. Certainty, however, may be important for establishing bright line rules for Coasian bargaining. Bernstein's research shows that traders value bright line rules even when the rules are unfair or under-compensate when assessed against the standard expectation measure of contract damages. See discussion of Bernstein, supra note 4.

135. Hobhouse, supra note 131 , at 533 .

136. Roy Goode, Insularity or Leadership? The Role of the United Kingdom in the Harmonisation of Commercial Law, 50 INT'L\& COMP. L. Q. 751, 756(2001) [hereinafter Goode, Insularity or Leadership?].

137. Id. at 756-57.

138. Id. at 757 .

139. Id.

140. Id. 
and Wales, "we have long ago ceased to take an interest in servicing even our own general law. The Victorians had the foresight to expend large amounts of time, energy and money in providing an infrastructure that would last 100 years. We do not have this vision." ${ }^{41}$ Professor Goode contends that this is a matter of "utmost gravity." ${ }^{142}$ Most of the commercial statutes on the books in the UK do date from the late nineteenth and early twentieth centuries. ${ }^{143}$

- Finally, a deep seated aversion to codification persists among some members of the legal profession in England and Wales. According to Justice Hobhouse, "utopian ideals" led to the situation of having conventions such as the CISG, and such unification efforts are comparable to the movement for the adoption of Esperanto as a universal language. ${ }^{144}$

These, at least, are the conventional or "official" reasons for the British rejection of the CISG and British skepticism towards law unification generally. At the European level, the concern about the sanctity of the common law as a minority tradition also may be a reason for Britain to eschew unification, but at the international level the concern has less credibility because of the substantial involvement of other major common law countries in unification efforts, notably Australia, Canada and the United States. ${ }^{145}$

\section{b. The Reasons Through the Lens of Public Choice}

Now we proceed to the rational choice oriented reasons for the British refusal to ratify the CISG. To be consistent in our analysis of these questions using political economics, the above contentions have to be critically assessed through the lens of public choice. A reasonable suspicion exists, based on strong intuition, that the actual reasons for rejecting the CISG are that it would injure powerful interest groups in the

\section{Id. at 758 .}

142. Id.

143. See, e.g., Bills of Exchange Act 1882; Marine Insurance Act 1906. The Sale of Goods Act 1979 consolidated its 1893 predecessor and its amendments. Ewan McKendrick, Sale of Goods, in 2 ENGLISH PRIVATE LAW 223 (Peter Birks ed., 2000).

144. Hobhouse, supra note 131, at 534-35.

145. See Nicholas, supra note 130. 
United Kingdom, namely, legal London.

Legal diversity can be a tool for protectionism. Whether or not a particular industry group will support or oppose unification depends on whether they have a fear of foreign competition and wish to maintain monopoly power over industry activities. The incentive to promote legal diversity may flip to an incentive to promote unification when the industry loses interest in maintaining legal differences because it sees opportunities to further their interests in other jurisdictions ${ }^{146}$ Lawyers in this respect are no different than bankers, insurers, telecommunications firms and other service providers. In international commercial law, the British legal industry has incentives to pursue legal diversity and to defeat unification, and have been successful in doing so. I base this tentative finding on the following six propositions.

\section{i. Legal London Has Benefited from Legal Diversity}

In its 1980 report on the CISG, what was then the Law Reform Committee of England and Wales recommended against CISG ratification. The relevant report said, among other things:

If the Convention were ratified by the UK and . . . came to be widely applied to international sales, with or without a connection with this country, the role of English law in the settlement of international trading matters would obviously be diminished. A consequential effect might well be a reduction in the number of international arbitrations coming into this country. ${ }^{147}$

Legal London, an integral part of what has become known as "UK plc," has produced significant "invisible earnings" for the United Kingdom. ${ }^{148}$ In the 1990s, the UK generated substantial surpluses of invisible earnings, in the range of $£ 8-10$ billion, the largest of the G7 countries relative to

146. Jürgen Basedow, The Case for a European Insurance Contract Code, 2001 J. Bus. L. 569 (2001).

147. Law Reform Committee Report, quoted in Angelo Forte, The United Nations Convention on Contracts for the International Sale of Goods: Reason and Unreason in the United Kingdom, 26 BALT. L. REV. 51,58 (1997).

148. Invisible earnings consist of income from trade in services and from overseas assets. See UK Department of the Treasury, Occasional Paper No. 7, in INVISIBLE EARNINGS: THE UK'S HIDDEN STRENGTH (1996). 
gross domestic product. ${ }^{149}$ Legal services contributed about $£ 800$ million a year in UK invisible earnings in the late 1990s, but legal services are no longer generating the main surpluses; those are generated by financial and business services. ${ }^{150}$ Still, the legal services industry continues to grow in London, and the London law firms have led the world in globalization and consolidation. As of February 2001, four of the twelve largest law firms in the world were London based, and twenty-five percent of their lawyers are based outside of the UK, compared to American firms, who have only ten percent based outside the U.S. ${ }^{151}$

The United Kingdom has designated its Queens Bench Division of the High Court as the "Commercial Court," and it is in part intended to serve as a forum for the resolution of international commercial disputes, even where the parties to the dispute have no connection to the United Kingdom. The Court has existed for over 100 years. ${ }^{152}$ The work of the Court focuses most significantly on litigation relating to carriage of goods and charter parties, insurance and reinsurance, commodity transactions and litigation of issues relating to arbitral proceedings. ${ }^{153}$ The Court and the profession generally have been accommodating to foreign parties. In the words of Lord Denning:

No one who comes to these courts asking for justice should come in vain. . . . This right to come here is not confined to Englishmen. It extends to any friendly foreigner. He can seek the aid of our courts if he desires to do so. You may call this "forumshopping" if you please, but if the forum is England, it is a good place to shop in, both for the quality of the goods and the speed of service. $^{154}$

On appeal, the House of Lords disavowed Lord Denning's dicta, ${ }^{155}$ but it does reflect an international private law tradition. In Amin Rasheed $v$.

149. Lord Chancellor's Department, COMMERCIALCOURT FEASIBILITY STUDY $\S 3$, p. 15 (Feb. 2001) [hereinafter Cap Gemini Report].

150. Id.

151. Id.

152. ROY GOODE, COMMERCLAL LAW 1170 (2d ed. 1999).

153. Id.

154. Friedrich K. Juenger, Forum Shopping, Domestic and International, 63 TUL. L. REV. 553, 564 (1989) (quoting The Atlantic Star, [1973] 1 Q.B. 364, 38182).

155. The Atlantic Star, [1974] A.C. 436, 454 (per Lord Reid). 
Kuwait Insurance Corp. ${ }^{156}$ Lord Diplock noted that the Commercial Court is much the forum of preference of nationals from a wide range of countries. ${ }^{157}$ One essential English conflict of laws treatise, asserts that "there is a public interest in allowing trial in England of what are, in essence, foreign actions. When foreigners litigate in England this forms a valuable invisible export, and confirms judicial pride in the English legal system."158 In Miliangos v. George Frank (Textiles) Ltd. No. 1, ${ }^{159}$ the House of Lords held that English courts should render judgments in money damages in foreign currency, in order to maintain the institutional advantages of the courts in resolving international disputes. As Lord Kerr explained in an article discussing the Miliangos case: "Foreigners have confidence in our legal system. But they no longer have confidence in sterling. They can now continue to contract in stabler currencies, but continue to come here for the resolution of their disputes, without the danger of having to accept payment in sterling at a devalued rate." ${ }^{160}$ As well, a significant case load of international commercial arbitration occurs in London, either under the auspices of the London Court of International Arbitration, the ICC or as ad hoc arbitration. ${ }^{161}$

Despite these impressive credentials, the perception in the legal community is that English law and English legal institutions are losing ground, particularly to American legal institutions located in New York City. The Lord Chancellor was sufficiently concerned to commission a study, performed by Cap Gemini. ${ }^{162}$ The aim of the study was "to examine the potential for establishing a new Commercial Court in London to handle a wide range of high-value and international commercial litigation and to develop Britain's role as a global centre for dispute resolution," which would be "capable of attracting legal business from around the world."163 Some of the discussion in the report is telling:

156. [1984] A.C. 50

157. Id. at 67.

158. G. CheshiRe et al., PRIVATE InTERnational Law 233 (13th ed. 1999), see also J. Fawcett, Forum Shopping: Some Questions Answered, 35 N. IR. LEGAL Q. 141, 146 (1984), cited in Juenger, supra note 154.

159. [1976] AC 443.

160. Lord Kerr, Modern Trends in Commercial Law and Practice, 41 MOD.L. REV. 1, 10 (1978), quoted in Forte, supra note 147, at 59.

161. Cap Gemini Report, supra note 149, §3, at 19.

162. Id.

163. Cap Gemini Report, supra note 149, § 5. 
[F]or the non-practitioner the whole system is opaque to the point of miasma. It is inherently producer rather than customer-driven. It is quite a closed system and thus would appear to be inimicable to the Lord Chancellor's wider civil justice objectives. Such closed systems in the commercial world tend to exploit special knowledge to charge highly and to create barriers to new service providers, although it is impossible to tell from the information available whether this is true of commercial litigation. They are difficult systems to manage because information about them is inadequate. They tend to create inefficiencies by creating specialisms within specialisms. ${ }^{164}$

The recent debates on the question of whether the European Commission should be involved in the unification of contract law in the European Union provides more evidence. The Law Society of England and Wales, the professional association representing solicitors, dismissed the project in a terse one page letter, asserting that EU action is unnecessary. The Law Society argued that for commercial contracts, the inclusion of a choice of law clause "is now common practice and usually surmounts any difficulties." ${ }^{165}$ As for consumer contracting, the Law Society advocated the use of directives to regulate in particular areas. The General Bar Council of England and Wales, the professional association representing the barristers, was explicit in identifying one of its two main reasons for rejecting European unification of contract law was that it "would destroy a significant invisible export of the European Union."166 The Bar Council found this risk to be "real and tangible:"

Every year a large number of international commercial contracts are concluded, which provide for English law as their governing law, and subject the parties' disputes to the jurisdiction of English courts. Often this is done despite the fact that neither of the contracting parties is domiciled in England, and the contract has no obvious connection to England as a system of law. In this way

164. Id.

165. Id.

166. Communication on European Contract Law, A Position Paper on Behalf of the Law Reform Committee of the General Bar Council of England and Wales, Oct. 12, 2001, available at http://europa.eu.int/comm/consumers/cons_int/safe shop/fair_bus_pract/cont_law/comments/4.14.pdf (last visited June $\overline{26}, 2003$ ) [hereinafter Bar Council Position Paper]. 
English law is acting as an invisible export from the UK, and often (where businesses domiciled in non-contracting states are involved, as is frequently the case) from the European Union, creating work for the lawyers involved in the drafting of such contracts and for lawyers assisting in the resolution of disputes arising out of such contracts. ${ }^{167}$

The Bar Council submission continues, arguing that the "considerable UK (and often European) legal export risks being undermined if a mandatory scheme of unified European contract law were to be introduced."168 Further, according to the Bar Council, if European contract law is unified:

The volumes of international commercial business which are currently drawn to UK legal market would decline, and international businesses would start to favor different systems of governing law and jurisdiction. In this regard it is interesting to note that the Cap Gemini report found that most commercial organizations perceived New York and the US in general as being the main competitors to English law and venue. ${ }^{169}$

The remainder of the Bar Council submission presents what some might find to be an awkward explanation of the differences between the common law and the civil law, to the effect that stare decisis, and the lack of a good faith doctrine and other common law contract doctrines make English common law "better" for commercial dealings that continental law. ${ }^{170}$

Some might argue that if there is jurisdictional competition, English law and legal institutions have an incentive to provide efficient contract and commercial rules and systems of dispute resolution, or at least, rules and institutions that contracting parties prefer. This indeed may be the case. The anecdotal evidence to date, however, when reviewed as a whole, suggests at least a reasonable suspicion is in order. Persons and firms in Britain may be better off if certain efficiency benefits accrue to British firms and consumers who could benefit from unification both in Europe and beyond Europe. Moreover, British legal institutions would not lose

167. Id.

168. Id. at 4.

169. Id.; see also Letter from the Commercial Bar Association to the European Commission (Oct. 12, 2001) (on file with The Wayne Law Review).

170. See Bar Council Position Paper, supra note 166. 
their expertise in making consistent decisions, nor would stare decisis be abandoned, in the event of European unification or if the UK ratified the CISG. The legal establishment recognized these facts in a 1989 review of whether the UK should ratify the CISG. ${ }^{171}$ In the 1989 review, the perception of the profession (at least as it was expressed in the report of the Law Commission of England and Wales) was that accession would allow English courts and arbitrators to get market share in the resolution of disputes governed by the CISG and to participate in the development of its jurisprudence. ${ }^{172}$ This change of view would seem to relate to the fact that the United States-and hence New York-has ratified the CISG. Moreover, the United States has the UCC, restatements, and a substantial history of codification, yet it is England's main competition in the business of international commercial legal practice and dispute resolving.

\section{ii. Lawyers Outside of the International Commercial Legal} Establishment Either Are Rationally Ignorant of Unification Efforts or Prefer Unification

The United Kingdom is comprised of three legal jurisdictions. Devolution did not change this. England and Wales comprise a single common law jurisdiction. Northern Ireland is a single common law jurisdiction. Scotland is a mixed jurisdiction with significant civil law influences. There are number of lawyers practicing in regional legal centers in the UK, many of whom would either favor unification of the law dealing with the sale of goods and other areas of international commercial law, or are rationally ignorant about whether unification is worth pursuing. Scottish lawyers have an interest in CISG ratification, and little interest in protecting legal London; but, they cannot override English objections to the CISG. ${ }^{173}$ One Scottish lawyer explains that Scottish lawyers tend to favor CISG ratification because:

Scotland is a small jurisdiction and its laws, judicial system, and legal profession are an unknown quantity to many foreign businesses. These are classic reasons for not choosing the law of any small country as the proper law of an international contract for the sale of goods, or for arguing that Scots law does not govern the

171. Forte, supra note 147 , at 65.

172. Id.

173. See generally id. 
contract and that its courts have no jurisdiction to hear a dispute. But, if the Scots law on formation of contracts for the sale of goods were to be that set out in the UN Convention, and thereby constitute a neutral system of law, then, litigation or arbitration in Scotland might not seem so unattractive and that, of course, would be good for the business of the law. ${ }^{174}$

The rational choice analytics of political participation, as Anthony Downs and Mancur Olsen have pioneered, offers insights as to why legal London can maintain a stronghold on decisions by the British government on. whether to participate in international private law unification. Rational ignorance of the benefits and costs of unification allow special interest groups to have disproportionate power over the unification agenda. Two costs of political participation, or political transaction costs, seem worthy of analysis: the costs of information and the costs of organization. When the expected benefits of information are small relative to the costs, people acquire little information because to do so would not make them better off. ${ }^{175}$ The larger and more geographically diverse the group, the costlier it is to organize and the smaller the expected benefits. Thus, when we compare the two relevant groupings-lawyers whose interests are in maintaining their international commercial law expertise (mainly situated in London) and all other lawyers in the United Kingdom (spread across several regions)-the explanatory power of the rational choice argument seems compelling.

\section{iii. The British Legal Establishment Prefers International Cooperation in Areas Outside of Commercial Law}

The position that the United Kingdom has taken on ratification of a private law instrument such as the CISG stands in stark contrast to its efforts in non-commercial law treaty ratification. The UK was the fortysecond state to ratify the Rome Treaty on the International Criminal

174. Forte, supra note 147 , at 55.

175. ANTHONY DOWNS, AN ECONOMIC THEORY OF DEMOCRACY 207-76 (1957). Much of the subsequent economic analysis of politics builds on the assumption that these "Downsian" incentives foster rational ignorance. See, e.g., Mancur Olsen, The logic of Collective Action: Public GoOds and the THEORY OF GROUPS (1965); SAMUEL POPKIN, THE REASONING Voter: COMMUNiCATION AND PERSUASION IN PRESIDENTIAL CAMPAigns (1991). 
Court. ${ }^{176}$ For example, the UK has passed implementing legislation, the International Criminal Court Act 2001. ${ }^{177}$ This Act makes sweeping changes to English criminal law, law that directly affects substantial numbers of British citizens not involved in any activity outside of the borders of the country. It provides the first statutory definition of intent in English criminal law. ${ }^{178}$ The implementing statute was passed at an early stage "with a view to having a significant influence over the development of the [International Criminal Court]."179

iv. The Proposition that English Law Is "Superior" to International Conventions and the Domestic Laws of Other Countries Has Significant Cultural Meaning but Is Largely Myth

The legal professions of particular nations tend to have their preconceptions about the relative skill and worth of their members. The British legal profession is no different. British lawyers and judges are deservedly proud of their great tradition, which has spanned the globe and which claims the United States legal system as one of its heirs. The United States and England comprise the two major common law traditions; much like France and Germany can make this claim in the civil law tradition. Hayek contended, and recent empirical studies provide evidence, that the common law is relatively more conducive to economic growth than the civil law. ${ }^{180}$ Although a contested proposition, some legal scholars assert

176. Human Rights Watch Press Release, U.K. Support for War Crimes Court "Significant," available at http://www.hrw.org/press/2001/10/icc-uk1004.htm(last visited Feb. 2, 2003).

177. International Criminal Court Act, Her Majesty's Stationary Office, available at http://www.hmso.gov.uk/acts/acts2001/20010017.htm(last visited Feb. 2, 2003).

178. The International Criminal Court Act 2001, 2001 CRIM. L. Rev. 767 (2001).

179. Id. at 767.

180. FrIEDRICH A. HAYEK, THE CONSTITUTION OF LIBERTY 162-75 (1960); FRIEDRICH A. HAYEK, LAW LEGISLATION AND LIBERTY 72-93 (1973); see also Rafael La Porta et al., The Quality of Government, 15 J. L. ECON. \& ORG. 222 (1999); Rafael La Porta et al., Law and Finance, 106 J. POL. ECON. 1113 (1998); Rafael La Porta et al., Legal Determinants of External Finance, 52 J. FNANCE 1131 (1997); Ross Levine et al., Financial Intermediation and Growth: Causality and Cause, 46 J. MONETARY ECON. 31 (2000); Ross Levine, Law, Finance and Economic Growth, 8 J. FIN. INTERMEDIATION 8 (1999); Paul G. Mahoney, The Common Law and Economic Growth: Hayek Might be Right, $30 \mathrm{~J}$. LEGAL STUD. 
that the intellectual leadership in law presently resides in the common law tradition. ${ }^{181}$

It would be impracticable and pointless to try to demonstrate that a legal system is "better" or "superior" than another based on the qualities of the legal rules or the institutions involved in legal decision making. English lawyers claim that their law provides certainty to commercial interests, with its precisely drafted statutes, its highly developed case law, and the high levels of expertise among its courts and lawyers. The numbers of intermational contracts that specify English law as the proper law of the contract support this claim. The expertise of the English judiciary and legal profession is not contested, but the preeminence of English law in international commerce may be the result of other factors as well, such as the size and significance of the capital markets situated in London, or the role of the United Kingdom as a liberal free trading superpower in the nineteenth century. It would be difficult to disentangle the various factors that led to the leadership of English law.

We can say, however, at this point in the twenty first century, that English law does not have a vast comparative advantage over its American or European counterparts. Sir Roy Goode, one of the preeminent legal scholars and practitioners of commercial law in the world, takes the view that "number of [the CISG's] rules are better than those found in our own Sale of Goods Act. . . ."182 Goode cites as an example the CISG rule that risk of loss of goods in a sales contract passes with control-delivery of actual or constructive possession of the goods-rather than with ownership. Goode finds unsatisfactory that English courts avoid the ownership rule through the legal fiction of inferring a contrary intention of the contracting parties. ${ }^{183}$

One example does not constitute proof, but it does at least suggest that the idea of English law as a superior being is largely mythical. The substantive provisions of the current English Sale of Goods Act 1979 dates largely from the initial promulgation of the Act in 1893. ${ }^{184}$ The Act continues the nineteenth century concept that risk of loss passes with title to goods. It is doubtful that this provision is efficient or reflective of contemporary commercial realities, where the parties would prefer risk to

503 (2001).

181. Mattei, Why the Wind Changed, supra note 37.

182. Goode, Insularity or Leadership?, supra note 136, at 755.

183. Id.

184. Id. at 762 . 
pass with control, thereby allocating risk to the least cost insurer. ${ }^{185}$ Other examples can be found, and it is not my place to spend time knocking down English law. I only want to make the limited point that English law is perhaps no better or worse than American law or the domestic law of other countries that have ratified the CISG.

\section{v. The Established Commodity Associations Exclude Uniform} Sales Laws from Application

Commercial persons want what formalists call "legal certainty." In contracts entered into between established merchants, little room exists for open textured standards or balancing tests in which judges (or arbitrators) have significant discretion. Predictability is more important than fairness; that a commercial party can predict a legal outcome is usually more important than the fairness of the outcome. Remedies too are sometimes under-compensatory so long as they are predictable. ${ }^{186}$ Certainty in the law is achieved through formalism. In order to produce a set of formal legal rules and formal modes of reasoning around those rules, trade associations create detailed standard form contracts for their particular industries. Important research in the United States has shown that traders in established markets do not rely on unwritten customs to delimit contract obligations. ${ }^{187}$ Rather, they use standard form contracts in repeat play settings. The research casts doubt on the legal realist framework of the Uniform Commercial Code, in which unwritten custom is supposed to fill gaps in contracts. ${ }^{188}$ In the United States, for example, contracts for the sale

185. See Shivbir S. Grewal, Risk of Loss in Goods Sold During Transit: A Comparative Study of the U.N. Convention on Contracts for the International Sale of Goods, the U.C.C., and the British Sale of Goods Act, 14 LOY. L.A. INT'L \& COMP. L. REV. 93 (1991).

186. See Bernstein, supra note 4. The intuition for acceptance of an ostensibly unfair contract term goes something like this. The under-compensatory nature of a remedy is less important where merchants are engaged in repeat relationships, or perhaps even where a merchant has many contracts for the same commodity. Merchants in such contexts are either more interested in the relationships than in extracting maximum profit or surplus from a particular transaction, or they may use multiple profitable transactions to cushion an occasional loss transaction.

187. Id.

188. David Charny, The New Formalism in Contract, 66 U. CHI. L. REV. 842 (1999); Richard A. Epstein, Confusion About Custom: Disentangling Informal Customs from Standard Contractual Provisions, 66 U. CHI. L. REv. 821 (1999). 
of hay, textiles, silk and cotton are governed by standard form contracts developed by trade associations. ${ }^{189}$ Trade associations in the United Kingdom maintain standard form contracts for the sale of oils, seeds and fats, grain and cotton. ${ }^{190}$

That these standard form contracts are used does not mean that the law does not have a gap-filling role, though that role may be diminished or different in character. Courts and arbitrators are more likely to be involved in interpreting clauses rather than in filling significant gaps with formal legal rules. Common law courts may make precedent concerning particular clauses. Arbitral tribunals, while not producing precedent in the strict sense of the meaning of that concept in the common law, nevertheless produce consistent contract interpretations upon which to settle expectations, particularly when the tribunal is one established by the trade association itself, or one which must follow the arbitral rules of the association. ${ }^{191}$

English law is incorporated into the standard form contracts of the major commodity associations located in the United Kingdom. English law is made applicable despite that many of the parties who enter into contracts using these forms are not English, and contract performance often occurs wholly outside of England. Two examples, from the standard form contracts of two trade associations located in London, are provided here. The Federation of Oils, Seeds and Fats Associations (FOSFA) Contract No. 53 contains Clause 27, entitled "Domicile," which provides in pertinent part as follows:

This contract shall be deemed to have been made in England and the construction, validity and performance thereof shall be governed in all respects by English Law. ${ }^{192}$

Contract No. 53 also contains Clause 28, immediately following the Domicile clause, entitled "International Conventions," which excludes the application of the CISG, its predecessors, as well as the UN Convention on

189. Bernstein, supra note 4.

190. Michael BRIDGe, The International Sale of GoOds: LAW AND PRACTICE 2 (1999). All references to the standard form contracts in this article are solely to those contracts as they are found in the Bridge text.

191. See, e.g., Federation of Oils, Seeds and Fats Associations (FOSFA) Contract No. 53, Clause 29 "Arbitration," reprinted in BRIDGE, supra note 190 app. 1, at 455; Grain and Feed Trade Association (GAFTA) Contract No. 100, Clause 32 "Arbitration," reprinted in BRIDGE, supra note 190 app. 1, at 465-66.

192. BRIDGE, supra note 190 app. 1, at 454. 
Prescription (Limitation) in the International Sale of Goods. ${ }^{193}$ The Grain and Feed Trade Association (GAFTA) Contract No. 100 for the shipment of feedstuffs in bulk also contains a clause entitled "Domicile," Clause 31, which provides in pertinent part as follows:

Buyers and sellers agree that, for the purpose of proceedings either legal or by arbitration, this contract shall be deemed to have been made in England, and to be performed there, any correspondence in reference to the offer, the acceptance, the place of payment or otherwise, notwithstanding, and the Courts of England or arbitrators appointed in England, as the case may be, shall, except for the purpose of enforcing any award made in pursuance of the Arbitration Clause hereof, have exclusive jurisdiction over all disputes which may arise under this contract. Such disputes shall be settled according to the law of England, whatever the domicile, residence or place of business of the parties to this contract may be or become. Any party to this contract residing or carrying on business elsewhere other than in England or Wales, shall for the purpose of proceedings at law or in arbitration be considered as ordinarily resident or carrying on business at the offices of the Grain and Feed Trade Association [in London], and if in Scotland, he shall be held to have prorogated jurisdiction against himself to the English Courts; or if in Northern Ireland to have submitted to the jurisdiction and to be bound by the decision of the English Courts. ${ }^{194}$

GAFTA Contract No. 100 also contains a Clause 33, which is identical to Clause 28 in FOSFA Contract No. $53 .{ }^{195}$

Thus, the major trade associations in the UK would seem to have no interest in using any lobbying power they might have to promote the ratification by the UK of a uniform sales law, such as the CISG. Members of the legal profession who are experts on the standard form contracts also

193. Id. at 455 . Some have argued that the CISG is tailored more towards manufactured goods than commodities. Williams, supra note 127.

The predecessors to the CISG were the Uniform Law on the Formation of Contracts for the International Sale of Goods and the Convention relating to a Uniform Law on the International Sale of Goods. These were implemented in the United Kingdom in the Uniform Laws on International Sales Act 1967.

194. BRIDGE, supra note 190 app. 1 , at 465.

195. Id. 
would lack an interest in change. If the UK were to ratify the CISG, the trade associations would have to continue to exclude the application of the CISG if they want to continue the positive externality that their standard forms provide in their industries. ${ }^{196}$ One hears that the trade associations opposed CISG ratification in early consultation efforts initiated by the British government, but this opposition is difficult to document and is likely to have dissipated in subsequent consultation efforts. It is an intuitively plausible proposition that the trade associations would at the very least be indifferent to UK ratification of the CISG.

\section{States Unify Around Institutional Blockage: The Harmonizing Tendencies of the EU Constitutional Order}

EU law is a large subject and this article does not provide any sort of detailed or nuanced inquiry into it. Nor does it delve into recent initiatives to enlarge the EU or to produce a written constitution for the EU. ${ }^{197}$ What is provided here is a basic and tentative institutional analysis, an elaboration of a theory, which merits separate detailed treatment beyond this article.

The EU is a substantial lawmaking project. The EU institutions have produced and continue to augment a large body of EU law, in the form of directives, regulations, decisions and even a case law in decisions of the European Court of Justice. EU officials exercise their preferences in the context of the institutions in which they operate. The EU cannot seek to achieve unification of law as nation-states do. EU institutions make feasible a form of harmonization at the European level that allocates authority to EU institutions to establish basic norms that EU member states are bound to follow in their own national law. In complex areas of the law, the EU institutions direct member states to adapt their national laws to EU norms.

The EU has limited means to produce pan-European legal rules. The formal typology of EU legislative tools is regulations, directives and decisions. ${ }^{198}$ A regulation has direct effect in the EU member states. ${ }^{199} \mathrm{~A}$ directive is binding on the member state in terms of outcome, but how that outcome is accomplished is within the discretion of the member state. ${ }^{200} \mathrm{~A}$

196. See Avery W. Katz, Standard Form Contracts, in The NEW PalgRAVE DICTIONARY OF ECONOMICS AND THE LAW (1998).

197. For a comprehensive text on EU law, see PAUL CRAIG \& GRAINNE DE BúRCA, EU LAW: TEXT, CASES AND MATERIALS (3d ed. 2003).

198. European Community Treaty art. 249.

199. Id.

200. Id. 
decision is binding on those to whom it is addressed. ${ }^{201}$ In addition, the European Court of Justice produces a case law that is binding on member states.$^{202} \mathrm{EU}$ institutions also produce a range of soft law instruments, such as guidelines, policy statements and declarations. ${ }^{203}$ The EU institutions have no authority to promulgate the traditional sorts of legislative instruments widely used by nation-states. Nor do they have the power to promulgate and promote anything like a uniform or model law.

The limited forms of legislative instruments available to the EU institutions are to be contrasted with the considerable power that those institutions have to promulgate rules using the available instruments. The European Commission is an especially vibrant law making institution. The Commission wields a great deal of power in the EU to promote centralization of law. EU institutional structure combines legislative, executive and judicial powers in the Commission. ${ }^{204}$ There is a lack of rigid separation of powers among the EU institutions. ${ }^{205}$ The Commission plays a central role in the legislative process. It can initiate legislation and indeed takes the lead in the EU bureaucracy on proposing legislation. The Commission has a monopoly on legislative initiative because the treaties determining the institutional structure of the EU provide that the Council and the European Parliament will act on legislative proposals from the Commission. ${ }^{206}$ The Commission also develops policy for the EU. Once legislation is passed, the Commission acts as an executive in enforcing the law, and has the power to sue member states in the European Court of Justice when a member state fails to adhere to legislation. ${ }^{207}$ The Commission is one the most significant agenda setters in the EU legal

201. Id. Decisions have few if any roles in producing significant legal change in the EU.

202. Cases 28-30/62, Da Costa en Schaake NV, Jacob Meijer NV \& HoechstHolland NV v. Nederlandse Belastikngadministratie, [1963] ECR 31. Da Costa "initiated what is in effect a system of precedent." CRAIG \& DE BÜRCA, supra note 197, at 440; see also Case 283/81, Srl CILFIT and Lanificio di Gavardo SpA v. Ministry of Health, [1982] ECR 3415; Case 66/80, International Chemical Corporation v. Amministrazione delle Finanze dello Stato, [1981] ECR 1191; Case 314/85, Firma Foto-Frost v. Hauptzollamt Lübeck-Ost, 1987] ECR 4199.

203. CRAIG \& DE BÚRCA, supra note 197 , at 111.

204. Id. at 59-62.

205. Id. at 54 .

206. Id. at 59-60; see also Roland Vaubel, The Centralisation of WESTERN EUROPE 36 (1995).

207. CRAIG \& DE BÚRCA, supra note 197 , at 60-61. 
environment, perhaps the most important one when it comes to law making. Both the Commission and the European Court of Justice are widely perceived as engines of integration in the European internal market.

History affects the allocation of law making activities in Europe. The Commission, or the EU institutions in combination, cannot simply pass a uniform commercial code for Europe. The EU member states maintain a strict dichotomy between public law and private law. ${ }^{208}$ The enumeration of powers in the various treaties governing the EU does not explicitly include harmonization or unification of private law per se, although an argument could be constructed that a substantial level of increased harmonization is necessary to promote the internal market. ${ }^{209}$ The treaties operate in the sphere of public law; powers and competencies are set forth in the language of achieving economic integration of a common market. ${ }^{210}$ The EU is supposed to be about elimination of trade barriers. Private law is too political in character to be handled by the EU institutions, at least at this time:

The national nature of private law was the product of more that simply a history of parallel legislative enactments by different States. Rather, it derived from the historical identification of civil codes with the political and ideological birth of the modern European nation-states. ${ }^{211}$

A number of provisions in the EU treaties seem designed to protect against encroachment on sovereignty as it is manifested in national private law autonomy. ${ }^{212}$

208. Daniela Caruso, The Missing View of the Cathedral: The Private Law Paradigm of European Legal Integration, 3 EUROPEAN L. J. 3 (1997); Ewoud Hondius, Towards a European Civil Code: General Introduction, in TOWARDS A EUROPEAN CIVIL CODE 1 (A.S. Hartkamp et al. eds., 1994).

209. Caruso, supra note 208, at 10; For a discussion of the substantive EU law, see CRAIG \& DE BúRCA, supra note 197.

210. See Peter-Christian Müller-Graff, Private Law Unification by Means Other than Codification, in TOWARDS A EUROPEAN CIVIL CODE, supra note 208, at 19.

211. Caruso, supra note 208 , at 9.

212. The subsidiarity principle found in EC Treaty and the concepts of mutual recognition and home country control, seem to promote an approach to harmonization which is vertical, based on use of directives to impose ends rather than codification, which imposes both means and ends. See Müller-Graff, supra 
If we assume that EU officials prefer centralized law to maximize their utility, then they will use their considerable power to promote centralized law, using the instruments at their disposal. EU officials work within the institutional framework. The institutions affect the form and content of the legal rules. ${ }^{213}$

\section{CONCLUSIONS: SOME MODEST RECOMMENDATIONS}

From the above analysis of how legal rules are made in the United States and Europe, the normative issue then, should be to produce institutional structures capable of counteracting the problems associated with inefficiencies in the law making process so that, in more cases than not, changes in the law will be Pareto efficient. What sorts of institutional constraints could states implement to promote efficiency improvements in the unification process? Consider these three:

\section{A. Commentaries Addressing Efficiency}

Model laws and international conventions tend to be accompanied by official commentary. States could require demonstrations in the commentary of efficiency improvements in the law. It would be naive to suggest that because the commentary says that the law is an efficiency improvement, that the law makers actually took efficiency into account in producing the law. ${ }^{214}$ That they are required to provide such an analysis, however, does at least five things to improve upon the status quo. First, it signals that unifying bodies are amenable to efficiency oriented approaches. Second, it produces information about the content of the law. Third, it has the potential to focus

note 210; Helen Hartnell, The New International Economic Order, 87 AMERICAN SOCIETY OF INT'L L. ProC. 459, 466 (1993); Norbert Reich, Competition Between Legal Orders: A New Paradigm for EC Law?, 1992 COMMONMARKET L. REV. 861 (1992).

213. Two examples of this phenomenon are in the areas of consumer protection and product liability. See, e.g., Geraint Howells, Product Liability, in Tow ARDS A EUROPEAN CIVIL CODE, supra note 208, at 313; Luisa Antoniolli Deflorian, Consumer Protection, Fair Dealing in Marketing Contracts and European Contract Law-A Uniform Law?, 2 GLOBAL JURIST FRONTIERS, article 4 (2002).

214. J. Mark Ramseyer, Public Choice, available at http://www.law. uchicago.edu/Lawecon/index.html (accessed from homepage by selecting Working Papers and then scrolling down to No. 034 and then selecting the PDF File link next to Ramseyer's Public Choice entry) (last visited Jan. 30, 2003). 
the drafting of law on improvements in the law rather than on legal change by itself as a goal. Fourth, it assists in getting law and economics scholars to review proposed laws. Fifth, it is difficult to "fake" efficiency. The public choice oriented explanations for unification will remain relevant, and actors involved in unification projects will not somehow miraculously begin to act only in the public interest. There are no panaceas. And, uncertainty will remain for some laws as to whether they actually will be efficient when implemented by courts. But still, drawing attention to efficiency should channel some law-unifying behavior towards the production of better or at least more efficient law.

\section{B. Random Reviews}

Governments and entities involved in private law unification could implement institutions that would result in the random selection of scholars, practitioners and judges for review of proposed laws. In order to be eligible, such persons must be experts who are not involved in the unification process. Bar associations and law societies could make participation mandatory in their rules of professional responsibility, or participation could be encouraged, as pro bono representation and voluntary work are encouraged in US codes of professional responsibility. 215

\section{Improving International Institutions}

Many of the complaints about divergent interpretations of unified laws are arguments for unification, in the form of an international body, such as an international court. Domestic courts likely have an inherent bias favoring domestic law and interpretation. A number of reasons exist for such bias, and this article is not the place for investigation of these reasons. Domestic judges and their staff are trained in their own domestic law and entrenched in their local interpretive community. ${ }^{216}$ They want to minimize successful appeals and their appellate courts perhaps tend to favor their own domestic law. They are also interested in the promotion of their own domestic law as a matter of prestige and in keeping the courts and their lawyers in work. The argument about how courts defeat unification by failing to interpret unified law uniformly is an argument for unification. Arguments about the need to

215. See, e.g., MODEL RULES OF PROF'L CONDUCT R. 6.1 (2002).

216. See Mattei, supra note 60 (discussing the need for a "common interpretive community" for successful European codification). 
improve the certainty or precision of unified law are a quest for a holy grail. Absolute certainty in the drafting of legal texts is impossible. A focus on courts sheds light on the real problem, the lack of an international commercial court system. It is a common economic argument that the focus of a particular policy prescription should be directly on the problem and not on some indirect approach.

The fate of private law unification ultimately will not depend on an analysis of ideal conditions. It is by now trite to say that institutions matter. The incentive structures of the institutions involved in private law unification will in large part determine the content of the laws these institutions produce. We still know next to nothing about what makes these institutions better or worse producers of legal products than courts and public legislatures, and we have made no attempts to improve the incentives of these institutions from a rational choice standpoint. Rather than simply give up on unification, or focus on what unifying institutions cannot do, this article tries to refocus the debate on constructive analysis of what they can do and how to make them better at improving the law. 
